Tarih Kültür ve Sanat Araştırmaları Dergisi

Revue des Recherches en Histoire Culture et Art

مجلة البحوث التاريخية والثقافية والفنية
Vol. 7, No. 4, December 2018

Copyright (C) Karabuk University

http://kutaksam.karabuk.edu.tr

\title{
DOI: 10.7596/taksad.v7i4.1763
}

Citation: İbret, B., Recepoğlu, E., Karasu Avcı, E., \& Recepoğlu, S. (2018). Öğretmen Adaylarının "Demokrasi" Kavramına Yönelik Metafor Algıları. Journal of History Culture and Art Research, 7(5), 421441. doi:http://dx.doi.org/10.7596/taksad.v7i5.1763

\section{Öğretmen Adaylarının “Demokrasi” Kavramına Yönelik Metafor Algıları}

\section{Perceptions of Prospective Teachers about the Concept of "Democracy"}

\author{
B. Ünal ibret ${ }^{1}$, Ergün Recepoğlu ${ }^{2}$, \\ Emine Karasu $\mathrm{Avcl}^{3}$, Serpil Recepoğlu ${ }^{4}$
}

\begin{abstract}
In this study, it is aimed to reveal the perceptions of 4 th grade prospective teachers studying in Kastamonu University with respect to the concept of democracy through metaphors. By giving emphasis on common objectives in line with the metaphors students produced, the inferences were made about what they understand from the democracy and direction of their perceptions. In accordance with the nature of the research, qualitative research design "phenomenological pattern" was used. The study group includes a total of 297 prospective teachers who voluntarily participate the study, including 76 men and 221 women girls studying in the fourth class in Kastamonu University Faculty of Education in the 2016-2017 academic year. A survey form, consisted of 1 open-ended question, was used as data collection tool to set students' perceptions. The participants were asked to fulfil the "Democracy is like ...... because ....." expressions featured in the survey form. Data were analyzed with content analysis technique. The data were analyzed by descriptive analysis. In the study, prospective teachers developed 149 different metaphors about the concept of democracy. According to the results obtained in this study, prospective teachers focused on most freedom sun, seesaw, water, balance, tree, equality, bird, life, justice, father, rainbow, sky, shield, breath, train and conscience metaphors. Teacher candidates see the concept of democracy with metaphors that they develop as a factor changing from the point of view. In the study, it was determined that the perception of democracy changed according to gender. In addition, it is seen that prospective teachers perceive democracy as different from each other according to their branches.
\end{abstract}

Keywords: Democracy, Prospective teachers, Metaphor.

\footnotetext{
${ }^{1}$ Faculty of Education, Kastamonu University, Kastamonu, Turkey. E-mail: bibret@kastamonu.edu.tr

${ }^{2}$ Faculty of Education, Kastamonu University, Kastamonu, Turkey. E-mail: erecepoglu@ kastamonu.edu.tr

${ }^{3}$ Faculty of Education, Kastamonu University, Kastamonu, Turkey. E-mail: eavci@kastamonu.edu.tr

${ }^{4}$ Faculty of Education, Kastamonu University, Kastamonu, Turkey. E-mail: melekrecepoglu@gmail.com
} 
Bu çalışmada, Kastamonu Üniversitesi'nde öğrenim görmekte olan çeşitli branşlara sahip dördüncü sınıf öğretmen adaylarının demokrasi kavramına ilişkin sahip oldukları algıları metaforlar aracılığıyla ortaya çıkarmak amaçlanmaktadır. Bu amaç doğrultusunda oluşturulan metaforların ortak özellikleri üzerinde durularak, yükseköğretimde öğrenim gören öğrencilerin demokrasi hakkındaki algılarının ne yönde olduğu ve demokrasiden ne anladıkları hakkında çıkarımlar yapılmıştır. Çalışmada nitel araştırma yöntemlerinden birisi olan olgubilim deseni kullanıımıştır. Çalışma grubu, 2016-2017 eğitim öğretim dönemi bahar yarıyılında araştırmaya gönüllü olarak katılmayı kabul eden 221'i kız 76'sı erkek olmak 297 öğretmen adayından oluşmaktadır. Öğretmen adaylarının belirlenen kavramlarla ilgili algılarının ortaya koyulması amacıyla veri toplama aracı olarak, bir adet açık uçlu sorudan oluşan form kullanılmıştır. Çalışmada öğretmen adaylarından "Demokrasi ... gibidir; çünkü ... ." ifadesini tamamlamaları istenerek veriler elde edilmiştir. Elde edilen veriler betimsel analiz yoluyla çözümlenmiştir. Çalışmada öğretmen adayları demokrasi kavramına yönelik 149 farklı metafor geliştirmişlerdir. Bu çalışmada öğretmen adayları bu metaforlardan en fazla özgürlük, güneş, tahterevalli, su, terazi, ağaç, eşitlik, kuş, hayat, adalet, baba, gökkuşă̆ı, gökyüzü, kalkan, nefes, tren ve vicdan metaforları üzerinde durmuşlardır. Öğretmen adayları geliştirdikleri metaforlarla demokrasi kavramını daha çok bakış açısına göre değişen bir unsur olarak görmektedirler. Çalışmada demokrasiyi algılama biçiminin cinsiyete göre değiştiği tespit edilmiştir. Ayrıca öğretmen adaylarının demokrasiyi branşlarına göre birbirlerinden farklı olarak algıladıkları görülmektedir.

Anahtar Kelimeler: Demokrasi, Öğretmen adayı, Metafor.

\section{Giriş}

Demokrasi eğitimi her geçen gün daha önemli hale gelmektedir. Demokratik toplumlarda eğitimin temel amaçlarından en önemlisi demokrasi kültürünü yerleştirmek ve demokratik vatandaş yetiştirmektir. Örgün eğitim kurumları bu açıdan ayrı bir öneme sahiptir. Bu eğitim kurumlarındaki eğiticiler demokratik yönetim ve yaşayış biçimini bir başka ifadeyle demokrasi kültürünü geliştirebilecek bir konumdadır. Bu nedenle yükseköğretim kurumlarında öğrenimine devam eden öğretmen adaylarının demokrasi kavramı ve kültürü hakkında gerekli birikimi almaları öngörülmektedir. Çünkü öğretmenlerin böyle bir hizmette bulunabilmesi için demokrasi kültürünü bir yaşam tarzına dönüştürmelerinin yanı sıra demokrasi ve demokrasiyle ilgili temel kavramları bilmeleri gerekmektedir. Bu temel bilgilerin yanı sıra, öğretmenlerin olumlu bir demokrasi algısına da sahip olması ayrıca önem taşımaktadır. Demokrasi algısının şekillenmesinde ise bireylerin yetiştiği aile ve içinde yaşadığı çevre kadar aldığı mesleki eğitimin de etkili olduğu bir gerçektir.

Demokrasi'nin geçmişi M.Ö. beşinci yüzyılda Yunanistan'da görülen şehir devletlerine kadar uzanmaktadır. Bu çağdaki anlamı "yurttaş egemenliği”nden ibarettir (Marshall, 2009). Zaten demokrasi kavramının etimolojisi incelendiğinde de yurttaş anlamındaki "demos" ve iktidar manasına gelen "kratein" sözcüklerinden oluştuğu görülmektedir (Schmidt, 2002 Akt. Demir, 2010). Atina demokrasisinin belirleyici özelliği, özel hayatın kamusal meselelere ve ortak çıkara feda edilmesini ifade eden yurttaşlık erdemine genel bir bağlılıktır (Şahin, 2008).

Demokrasi o dönem filozofları tarafından da ele alınmış ve tartışma konusu yapılmıştır. Platon'a göre demokrasi, en az iyi olan siyasi düzendir. Çünkü demokrasinin bir sapması olan kitlenin egemenliğine kolayca dönüşme ihtimali yüksektir. Bu durum en kötü siyasal düzen olan "tiranlığa” (zorbalığa) götürebilir. Aristoteles için demokrasi, en iyi siyasal düzen saydığı "politeia”nın bir sapmasıdır. Demokrasi yoksulların çıkarlarını, yani yurttaşların yalnızca bir kısmını korur, diğer sapkın kamu düzeni biçimleri gibi o da ortak 
yararı korumaz (Kuçuradi, 1998). Anlaşıldığı üzere demokrasi Antik Yunan'da doğrudan temsili şekliyle ele alınmıştır. Ancak iyi bir yönetim şekli olarak görülmemiştir.

Demokrasinin günümüzdeki manası ise başkadır. Modern dönem ile birlikte tekrar gündeme gelen demokrasi XX. yüzyıldan itibaren yaygınlı̆ı̆ı her gün biraz daha artırmıştır. Genel bir tabirle halk egemenliği anlamına gelen demokrasi, günümüzde en ideal yönetim biçimi olarak görülmektedir. Fakat demokrasinin farklı toplumlarda farklı anlamlar kazandığııı görebilmekteyiz. Bu açıdan demokrasinin tanımında fikir birliğinden söz etmek oldukça zordur. Demokrasi "devlet-toplum-birey” arasındaki ilişkiye bakılarak daha iyi anlaşılabilecek bir kavramdır.

Yıllardır tartışılan ve farkı tanımları yapılan demokrasi kavramı genel olarak literatürde üç şekilde yorumlanmıştır. Bu yorumlardan ilki demokrasinin bir yönetim biçimi olarak ifade eden anlayıştır. Savaş (2003) demokrasiyi, egemenlik hakkının halka ait olduğu bir siyasi sistem ve yönetim şekli olarak tanımlamıştır. Bir toplumda demokrasinin gerçekleşebilmesi, halkın yönetime geniş ölçüde katılmasına, farklı düşüncelerin serbestçe ifade edilebilmesine, toplumun çoğunluğun kararına uymasının yanı sıra azınlığın haklarının da korunmasına ve temel hak ve özgürlüklerin güvence altına alınmasına bağlıdır (Savaş, 2003). Akşin (2003), demokrasinin tam olabilmesi için eşitlik ve özgürlük esaslarına dayalı olmasının şart olduğunu vurgulamaktadır. Kıncal ve Işık (2003) literatürde yer alma sıklığına göre demokratik değerleri incelemiştir. Eşitlik, yaşama saygı, özgürlük, adalet, dürüstlük, iyiyi arayış, işbirliği, özgüven, hoşgörü, duyarlılık ve sorumluluk değerlerini temel demokratik değerler olarak ifade etmişlerdir. Dahl (2001), demokratik sürecin kriterlerini etkin katılım, oy kullanma eşitliği, bilinçli anlayış, gündemin kontrolü ve erişkinlerin dâhil olması şeklinde sıralayarak demokrasinin zorbalığı önlemek, temel haklar, genel özgürlük, kendi kaderini tayin etme, ahlaki özerklik, insani gelişme, temel kişisel çıkarların korunması, politik eşitlik, barış ve refah gibi arzulanan sonuçlar doğurduğunu belirtmektedir.

Demokrasi ile ilgili ikinci yorumlama genellikle demokrasinin bir yönetim biçimi olmaktan çok bir yaşam felsefesi, bir yaşayış biçimi olarak ele alınmasıdır (Gürşimşek \& Göregenli, 2004). Levin (1998) demokrasinin bir yaşam tarzı olarak görülmesi gerektiğini ifade etmektedir. Demokrasinin bir yaşam biçimi olması ile ilgili en etkili açıklama Dewey'den gelmiştir. Dewey (tarihsiz), demokrasinin özel, politik bir biçim, seçilmiş yöneticiler tarafından gerçekleştirilen bir yönetme biçimi olmasının çok ötesinde insan ilişkileri ve kişiliğin gelişmesi anlamına geldiğini belirtmiştir. Dewey (tarihsiz), demokratik yöntemlerin, parlamento, seçimler, partiler arası ilişkilerle sınırlı olduğunu bunların insanların günlük yaşamlarında birebir etkisinin olmadığını belirtmiştir. Bir başka deyişle, demokrasinin insan yaşamında bir karşıı̆ı̆ıın, günlük yaşantısında bir anlamının olması gerekmektedir. Demokrasi ile ilgili üçüncü yorumlama ise demokrasinin insan hakları boyutunu temel alan yaklaşımdır.

Demokrasi hakkında fikir birliği olmaması toplum içindeki bireylerin de demokrasiye farklı bakış açılarıyla yaklaşmalarına sebep olmuştur. Aslında bu kadar farklılığın olmasındaki temel etken, içinde bulunduğumuz çağdır. Dünyayı "büyük bir köy" haline getiren küreselleşme dediğimiz süreçte, devlet, giderek sermaye akışlarını kontrol edemez, sosyal güvenceleri sağlayamaz hale geldiğinden, ortalama yurttaşın gözünde önemini her geçen gün biraz daha kaybetmektedir (Yamaç, 2010). Kültürel farklılıkların ve yerel kimliklerin kabulü ve onları savunmayı içinde barındıran küreselleşme, aynı zamanda çok kültürlülük temelinde bir kimlik kavramını açığa çıkarmıştır. Bu gelişme devlet ve toplumda hızlı dönüşümlere sebep olmaktadır. Ulus devlete karşı baskı artmakta ve bir takım sınırlamalar getirmektedir (Aktaş, 2012). Bu süreç ayrıca demokrasinin ve bu yönetimi benimseyen idarelerin günümüz toplumlarıyla, din ilişkilerine ne kadar cevap verebildiği sorununu gündeme getirmiştir. Bu sorunlar demokrasinin meşruiyeti açısından önemli hal almıştır.

Günümüz siyasal sitemleri incelendiğinde demokrasinin sürdürülebilirliği tartışmaya açılmıştır. Her devlet kendince demokrasinin sürdürülebilmesine yönelik programlar hazırlayıp, uygulamaya çalışmaktadır. 
Demokrasinin sürdürülebilmesi için gerekli olan düzenlemeler hakkında Kuşat (2011) ekonomik gelişmenin sürdürülebilir kılınması, demokratik seçim sürecinin kurumsallaştırılması, sivil kontrol mekanizması ve sivil toplum, demokratik özelliklere sahip siyasal kültür oluşturulması, gerçek bir hukuk devletinin kurulması, aydın kesimin desteğinin sağlanması şartlarını sıralamaktadır.

Demokrasi kavramı bu gelişmeler ve tartışmalar ışığında günümüzde tartışılır hale gelmiştir. Toplumun bir kesimi tarafından en iyi yönetim şekli olarak tanımlanırken, farkıı bir kesim demokrasiye yönelik eleştirilerini sürdürmektedir. Demokrasi bütün eleştirilere rağmen günümüzde etkinliği ve gücünü sürdürmektedir. Daha iyi bir yönetim tarzı ortaya çıkmadıkça da demokrasinin devamılıı̆ı önemini koruyacaktır. Demokrasi kültürünün geliştirilmesinde ve demokratik değerlerin kazandırılmasında aileye, sosyal çevreye, örgün eğitim kurumlarına ve kitle iletişim araçlarına büyük görevler düşmektedir (Genç, 2006). Demokrasinin öğrenilmesi ise demokratik ortamlarda demokrasi eğitimi yoluyla sağlanabilir. Oğuz (2005) demokrasinin toplumun tüm kesimlerinde işleyebilmesi için demokratik davranışlara sahip bireylerin yetiştirilmesine gereksinim duyulduğunu vurgulayarak bunun için demokratik eğitimin, eğitim sisteminin temel felsefesi olması gerektiğini belirtmektedir.

Bir toplumda demokrasiye bakış açısı, o kültürün demokratik değerlere verdiği kıymeti de gösterir. Bu bağlamda bireylerin sahip oldukları demokrasi algısı bize toplumun bakış açısını yansıtır. Demokrasi algısının belirlenmesinde bireyler tarafından geliştirilen metaforlar ayrı bir öneme sahiptir. Metafor kelime olarak, Grekçe "metapherein" kelimesinden türetilmiş olup, meta (değiştirmek) ve pherein (taşımak) sözcüklerinin birleşmesiyle oluşturulmuştur (Levine, 2005). Metafor günümüzde, daha ziyade söylemi süslemeye yönelik bir söz sanatı olarak bilinmekle birlikte, metafor kullanımı genel olarak dünyayı kavrayışımıza yardım eden bir düşünme ve görme biçimi anlamına gelmektedir. Bilimsel araştırmalar göstermiştir ki metaforik düşünme biçimi, dil ve bilim üzerinde olduğu kadar, insanın günlük yaşamında kendini ifade edişi üzerinde de biçimlendirici bir etki yapmaktadır (Morgan, 1998). Metafor, iki nesne ya da kavramı birbirine bağlayan dilsel bir araç olarak ifade edilebilir. Metaforlar günlük konuşma dilinde isim, fiil veya sıfat olarak karşımıza çıkabilirler. Metaforun asıl amacı bir şeyi başka bir şeyin bakış açısı ile anlamlandırmaktır (Palmquist, 2001; Lakoff \& Johnson, 1980 Akt. Arslan \& Bayrakçı, 2006).

Metaforlar öğrencilerin özellikle zor kavram ve terimleri daha net bir şekilde anlamalarına yardımcı olarak soyut kavramların zihinde somutlaştıııması ve görselleştirilmesini sağlamakta ve böylece öğrenilen bilgilerin akılda daha uzun süre kalmasını ve daha kolay hatırlanmasını sağlayarak öğrenme motivasyonunu artırmaktadır. Eğitim yönetiminde metaforlar müfredat geliştirme ve planlamada; öğretim alanında öğrenmeyi teşvik etme ve yaratıcı düşünceyi geliştirmede, öğretmen eğitiminde ise metaforlar, öğretim uygulamalarını yönlendirmede ve öğretmenlerin modern eğitim anlayışlarındaki yerlerini belirlemede bir araç konumundadır (Arslan \& Bayrakçı, 2006).

Son yıllarda, dünyada olduğu gibi ülkemizde de metaforların belli başlı sosyal ortamlardaki faaliyetlere nasıl rehber olduğu, inançları, tutumları ve değerleri nasıl şekillendirdiği, örgütsel süreçleri nasıl gösterdiği ve örgütsel yaşamın oluşturulmasında nasıl vurgulandığına yönelik olarak ilginin arttığı görülmektedir (Çelikten, 2006). Bu ilgi hayatın her alanında olduğu gibi eğitim ve öğretim alanında da kendisini göstermektedir. Ülkemizdeki eğitim ve öğretim alanında yapılan bilimsel çalışmalarda metafor üzerine öğrencilerin okulu algılamaları (Balcı, 1999; Aydoğdu, 2008), öğretmenlerin öğrenci algıları (Sezgin, Koşar, Koşar ve Er, 2017), öğretmen adaylarının öğretmen kavramına bakış açıları (Cerit, 2008; Ocak \& Gündüz, 2006; Pektaş \& Kıldan, 2009; Saban, 2004), öğretmen eğitim programları (Oğuz, 2005), düşünme ve öğrenme yaklaşımı (Arslan \& Bayrakçı, 2006) ve coğrafya kavramı (Öztürk, 2007) gibi çok farkı konularda araştırmalar yapılmıştır.

Öğretmen adaylarının demokratik değer ve tutumları Türkiye'de araştırma konusu yapan çalışmalar yeterli sayıda olmasa da mevcuttur. Bu çalışmaların bazılarında öğretmen adaylarının demokratik değer ve 
tutumlara yeterli düzeyde sahip oldukları (Akın \& Özdemir, 2009; Saracaloğlu, Evin \& Varol, 2004; Yazıcı, 2011) belirtilmektedir. Çankaya ve Seçkin (2004) ve Kılıç (2010) tarafından yapılan çalışmalarda ise öğretmen adaylarında demokratik değer ve tutumların yeterince gelişmediği yönünde bulgular dikkat çekmektedir. Yıldıım, Akbaşlı ve Şahin (2010) tarafından yapılan araştırmada öğretmen adaylarının demokratik inanç düzeylerinin öğretmenlere göre düşük olduğu saptanmıştır. Kılıç’ı (2010) çalışmasında ise öğretmen adaylarının üniversitedeki dört yıllık eğitimleri boyunca, demokratik anlayışlarında hiçbir değişim olmadığı ifade edilmiştir. Hâlbuki Koşar (2016) da çalışmasında üniversitelerin toplumsal gelişim ve değişim açısından öneminden bahsetmektedir.

Osler ve Starkey (2006), demokratik vatandaşık eğitimi uygulamalarında öğretmen yetiştirme konusunun önemini vurgulamaktadır. Demoulin ve Kolstad (2000), ABD’nin üç eyaletinde öğretmen adaylarının demokratik değerleri kazanma düzeyini araştırmıştır. Bulgularda sınıf düzeyi yükseldikçe öğretmen adaylarının demokratik tutum puanlarının da arttığı saptanmıştır. Wilkins $(1999,2001,2003)$ tarafından yapılan çalışmalarda ise ingiliz öğretmen adaylarının, demokratik vatandaşıı eğitimine ve okulların bu konudaki sorumluluğuna yönelik inançlarının yüksek olduğu saptanmış olmakla birlikte öğretmen adaylarının aldıkları eğitimin kendilerini birer öğretmen olarak bu rollere yeterince hazırlamadığını düşündüklerini belirlenmiştir. Hizmet öncesi eğitimlerinde demokrasiyi içselleştirememiş öğretmen adaylarının, mesleğe atıldıktan sonra sınıflarında demokrasinin yaşandığı ortamlar yaratmaları beklenemez. Branşı ve görev alacağı eğitim tür ve kademesi ne olursa olsun tüm öğretmen adaylarının, demokratik değerlere sahip bireyler olarak yetişmeleri, okullarda demokrasi kültürünün oluşturulabilmesi için oldukça önemlidir. Öğretmen adaylarının demokrasi anlayışlarını geliştirme ve demokrasiyi bir yaşam biçimi olarak benimsemelerini sağlama konusunda yapılacak her araştırma, öğretmen yetiştirme programlarının geliştirilmesi ve uygulanmasına katkı sağlayacaktır. Bu bağlamda bu çalışmada öğretmen adaylarının demokrasi kavramı hakkındaki algıları geliştirmiş oldukları metaforlar aracılığıyla belirlenmeye çalışılmıştır. Bu kapsamda aşağıdaki sorulara yanıt aranmıştır:

1. Öğretmen adaylarının demokrasi ile ilgili görüşleri nelerdir?

2. Öğretmen adaylarının demokrasiye ilişkin geliştirdikleri metaforlar ve bu metaforları kullanmalarının gerekçesine yönelik açıklamaları nelerdir?

\section{Yöntem}

\section{Araştırmanın Modeli}

Bu çalışmada, nitel araştırma modellerinden biri olan olgubilim (fenomenoloji) kullanılmıştır. Olgubilim (fenomenoloji) modeli, bir olguya ilişkin kişisel deneyimleri temel alır ve bu deneyimler üzerinden sosyal gerçeklere ulaşmayı hedefler (Ersoy, 2016). Olgubilim deseninde, farkında olunan ancak derinlemesine ve ayrıntılı bir anlayışa sahip olunmayan olgulara odaklanılır (Yıldıım \& Şimşek, 2016). Demokrasi soyut bir kavram olup, ilkeleri, değerleri, uygulama biçimleri sıklıkla tartışılan bir olgudur. Bu araştırmada öğretmen adaylarının demokrasi kavramına ilişkin algıları, metaforlar aracılı̆̆ıyla incelenmeye çalışılmıştır. Mecaz sözcüğü ile eş anlamlı kabul edilen (Türk Dil Kurumu [TDK], 2018) metafor kavramını Lakoff ve Johnson (2005), insan bilişinin temeli olarak görmektedir. Araştırmalarda metaforların kullanımı, bir durum, olay ve olguyu var olduğu haliyle betimlemede ve çalışılan konu, olgu, olay ve durum hakkında sağlam, zengin bir resim sunmada oldukça yararlıdır (Yıldırım \& Şimşek, 2016). Schmitt (2005) de özellikle nitel araştırmalarda ulaşılan karmaşık bilgilerin açık ve anlaşılır örüntülere dönüştürülmesinde, metaforların çok kullanışlı olduğunu belirtmektedir. Bireylerin kullandıkları metaforlar aracılı̆ııla, vermek istedikleri anlamlar ortaya çıkarılmaya çalışıı (Parsons, Brown \& Worley, 2004). Bu çalışmada da demokrasi kavramına yönelik öğretmen adaylarının algılarını anlayabilmek amacıyla olgubilim modeli tercih edilmiştir. 


\section{Çalışma Grubu}

Bu çalışmanın çalışma grubunu 2016-2017 öğretim yılı bahar yarıyılında Kastamonu Üniversitesi'nde öğrenim görmekte olan ve çeşitli branşlara (Sosyal Bilgiler Öğretmenliği [SB], Sınıf Öğretmenliği [S.Ö.], Fen Bilgisi Öğretmenliği [F.B.], Okul Öncesi Öğretmenliği [O.Ö.], Türkçe Öğretmenliği [T.Ö.], Matematik Öğretmenliği [M.Ö.]) sahip öğretmen adayları oluşturmaktadır. Öğretmen adayları çalışmaya gönüllü olarak katılmayı kabul eden 297 kişiden oluşmaktadır. Bu çalışmada amaçlı örneklem türlerinden biri olan maksimum çeşitlilik örneklemesi kullanılmıştır. Maksimum çeşitlilik örneklemesi, bir probleme ilişkin çeşitlilik gösteren durumlar arasında ortak paylaşılan olguların olup olmadığını bulmaya çalışmak amacıyla tercih edilen örneklem türüdür (Yıldırım ve Şimşek, 2016: 119). Bu çalışmada da demokrasi kavramına yönelik çeşitli branşlardan oluşan öğretmen adayları tercih edildiği için maksimum çeşitlilik örneklemesi kullanılmıştır. Çalışmaya katılan öğretmen adaylarının cinsiyete ve branşlara ilişkin frekans ve yüzdeleri aşağıdaki gibidir:

Tablo 1. Çalışmaya Katılan Öğrencilerin Cinsiyete ve Branşlara Göre Frekans ve Yüzde Dağııımları

\begin{tabular}{|c|c|c|c|c|c|c|c|c|c|c|c|c|c|c|c|c|}
\hline \multirow{2}{*}{$\begin{array}{l}\text { Cinsiye } \\
t\end{array}$} & \multirow[t]{2}{*}{$f$} & \multirow[t]{2}{*}{$\%$} & \multicolumn{2}{|c|}{ S.B. } & \multicolumn{2}{|c|}{ S.Ö. } & \multicolumn{2}{|c|}{ O.Ö. } & \multicolumn{2}{|c|}{ F.B. } & \multicolumn{2}{|c|}{ T.Ö. } & \multicolumn{2}{|c|}{ M.Ö. } & \multicolumn{2}{|c|}{ Toplam } \\
\hline & & & $f$ & $\%$ & $f$ & $\%$ & $f$ & $\%$ & $f$ & $\%$ & $f$ & $\%$ & $f$ & $\%$ & $f$ & $\%$ \\
\hline KIz & 221 & $\begin{array}{l}74, \\
4\end{array}$ & \begin{tabular}{|l|}
6 \\
1
\end{tabular} & $\begin{array}{l}20, \\
5\end{array}$ & $\begin{array}{l}5 \\
5\end{array}$ & $\begin{array}{l}18, \\
5\end{array}$ & $\begin{array}{l}3 \\
5\end{array}$ & $\begin{array}{l}11, \\
7\end{array}$ & $\begin{array}{l}4 \\
4\end{array}$ & $\begin{array}{l}14, \\
8\end{array}$ & $\begin{array}{l}6 \\
3\end{array}$ & $\begin{array}{l}21, \\
2\end{array}$ & $\begin{array}{l}3 \\
9\end{array}$ & $\begin{array}{l}13, \\
1\end{array}$ & 297 & 100 \\
\hline Erkek & 76 & $\begin{array}{l}25 \\
5\end{array}$ & & & & & & & & & & & & & & \\
\hline $\begin{array}{l}\text { Topla } \\
\text { m }\end{array}$ & 297 & 100 & & & & & & & & & & & & & & \\
\hline
\end{tabular}

Tablo 1'e göre çalışmaya katılan öğretmen adaylarının \%74,4 ( $\mathrm{f}=221)^{\prime}$ 'ünü $k ı z, \% 25,5$ ( $\left.\mathrm{f}=76\right)^{\prime}$ 'ini ise erkek öğretmen adayları oluşturmaktadır. Tablo 1 branşlar bazında incelendiğinde ise en fazla \%21,2 ( $f=63$ )'sini Türkçe öğretmen adayları, \%20,5 ( $f=61)^{\prime}$ ini Sosyal Bilgiler öğretmen adayları, \%18,5 ( $f=55$ )' ini ise Sınıf öğretmen adayları oluşturmaktadır.

\section{Verilerin Toplanması}

Bu çalışmada veri toplama aracı hazırlanırken, öğretmen adaylarının demokrasi kavramına yönelik sahip oldukları algıları ortaya çıkarmada metaforların bir araç olarak kullanıldığı ilgili çalışmalar incelenmiştir (Yüce \& Demir, 2011; Sarı \& Sadık, 2011; Dündar, 2012; Gömleksiz, Kan \& Öner, 2012; Sadık \& Sarı, 2012; Güder \& Yıldırım, 2014; Anderson, 2001; Nasırcı \& Sadık, 2017). Literatürdeki bu çalışmalarda ilköğretim öğrencileri ve öğretmen adaylarının demokrasi kavramına ilişkin metaforlarının incelendiği görülmektedir. ilggili çalışmalar temel alınarak bu çalışmada da öğretmen adaylarından "Demokrasi .... gibidir; çünkü ........ ." ifadesini tamamlamaları istenmiştir. Öğretmen adaylarına yeterince düşünebilmeleri ve cümleyi tamamlayabilmeleri için 10-15 dakika süre tanınmıştır. Toplanan belgeler araştırmanın temel veri kaynağını oluşturmuştur.

\section{Verilerin Analizi ve Yorumlanması}

Bu çalışmada, elde edilen verilerin değerlendirilmesinde betimsel analiz tekniğinden yararlanılmıştır. Betimsel analiz, verilerin daha önceden belirlenen temalara, gözlem ve görüşme süreçlerinde kullanılan sorulara göre düzenlenmesidir (Yıldııı \& Şimşek, 2016). Bu çalışmada da öğretmen adaylarının geliştirdikleri metaforlar Yüce ve Demir (2011)'in "Polis adaylarının demokrasi kavramına ilişkin algılarının metaforlar aracılığıyla incelenmesi" adlı çalışmasından faydalanılarak kategorilere ayrılmıştır. Her metafor öğretmen adaylarının yaptıkları açıklamalar kapsamında metaforun kaynağından atfedilen düşünce 
kapsamında gruplandırılmıştır. Öğrencilerin geliştirdikleri metaforların analiz edilmesi ve yorumlanması dört aşamada gerçekleştirilmiştir (Yıldırım \& Şimşek, 2016):

Betimsel Analiz İçin Bir Çerçeve Oluşturma: Çalışmanın kuramsal çerçevesinden yola çıkılarak verilerin hangi temalar altında düzenleneceği belirlenir. Bu çalışmada ilk önce öğretmen adaylarına çeşitli kodlar verilmiştir. Örneğin S.B.Ö.A. kodu Sosyal Bilgiler öğretmen adaylarına ilişkin yapılan kodlamadır. Aynı şekilde diğer branşlara sahip öğretmen adayları bu şekilde kodlanmıştır (S.Ö.Ö.A., F.B.Ö.A., O.Ö.Ö.A., T.Ö.Ö.A., M.Ö.Ö.A.). Daha sonra veriler branşlar temel alınarak metaforlar teker teker kodlanmıştır. Çalışmaya katılan 297 öğretmen adayının 294'ünden geçerli geri dönüş alınmıştır. 3 öğretmen adayından elde edilen bulgular ise gerekçesiz metaforlar üretildiği için geçersiz sayılmıştır. Öğretmen adayları toplam 149 metafor üretmişlerdir. 294 öğretmen adayından elde edilen bulgular yukarıda da belirtildiği gibi Yüce ve Demir (2011)'in "Polis adaylarının demokrasi kavramına ilişkin algılarının metaforlar aracılığıla incelenmesi" adlı çalışmasından faydalanılarak bir çerçeve çizilmiştir.

Tematik Çerçeveye Göre Temaların iş̧lenmesi: Çalışmanın bu aşamasında veriler okunur ve daha önceden belirlenen çerçeveye göre düzenlenir. Bu çalışmada da veriler, yukarıda belirtildiği gibi Yüce ve Demir (2011)'in çalışmasında belirlenen çerçeveye göre düzenlenmiştir. Öğretmen adaylarııı yazdıkları metaforlar teker teker okunarak, her metafor metaforun konusu, kaynağı ve metaforun konusu ile metaforun kaynağı arasındaki ilişki bakımından analiz edilmiştir. Daha sonra bütün veriler frekans (f) ve yüzdeler (\%) halinde bilgisayar ortamına aktarılmıştır.

Bulguların Tanımlanması: Bu aşamada düzenlenen veriler doğrudan alıntılarla desteklenir. Çalışmanın bu aşamasında öğretmen adaylarından elde edilen veriler ilgili kategoriler başlığı altında çeşitli branşlara sahip öğretmen adaylarına ait doğrudan alıntılara yer verilerek bulgular tanımlanmaya çalışılış̧ır.

Bulguların Yorumlanması: Bu aşamada bulguların açıklanması, ilişkilendirilmesi ve anlamlandırılması yapılır. Bulgular arasında neden-sonuç ilişkisi kurulur. Farklı olgular arasında karşılaştırma yapııı. Bu çalışmada da elde edilen bulgular araştırmacılar tarafından neden-sonuç ilişkisi kurularak açıklanmış ve yorumlanmıştır.

\section{Çalışmanın Geçerlik ve Güvenirliğinin Sağlanması}

Geçerlik ve güvenirlik araştırmalarda inandırııılığı sağlayan iki önemli ölçüttür. Bu çalışmada geçerlik, elde edilen verilerin analiz sürecinin ayrıntılı bir şekilde açıklanması ve bulguların tanımlanmasında öğretmen adaylarının görüşlerine doğrudan yer verilmesi ile sağlanmaya çalışılmıştır (Yıldırım \& Şimşek, 2016). Çalışmada güvenirliği sağlamak amacıyla analizci üçgenlemesine başvurulmuştur. Analizci üçgenleme, iki veya daha fazla kişiye verilerin bağımsız olarak analiz ettirilmesi ve bulgularının karşılaştırılması olarak ifade edilmektedir (Patton, 2014). Çalışmanın güvenirliğini sağlamak amacıyla çalışmada yer alan diğer iki araştırmacının (biri eğitim bilimleri diğeri coğrafya eğitimi alanında iki öğretim üyesi) görüşlerine başvurulmuştur. Araştırmacılar farklı düşündükleri noktalarda bir araya gelerek uzlaşma sağlamışlardır.

\section{Bulgular}

Öğretmen adaylarının "demokrasi" kavramına yönelik metafor algılarını ortaya çıkarmayı amaçlayan bu çalışmada elde edilen bulgular tablolar halinde sunularak yorumlanmıştır. Araştırmaya katılan öğretmen adayları tarafından geliştirilen metaforlar alfabetik sıraya göre listelenerek her bir metaforu temsil eden öğrenci sayısına (frekansı) ve yüzde değerlerine Tablo 1'de yer verilmektedir: 
Tablo 1. "Demokrasi" kavramına ilişkin öğrenciler tarafından geliştirilen metaforlar

\begin{tabular}{|c|c|c|c|c|c|c|c|c|c|c|c|}
\hline \multirow{2}{*}{$\begin{array}{l}\text { Sira } \\
\text { No }\end{array}$} & \multirow[t]{2}{*}{ Metaforlar } & \multicolumn{2}{|c|}{ Cinsiyet } & \multicolumn{6}{|c|}{ Bölüm } & \multicolumn{2}{|c|}{ Toplam } \\
\hline & & $\mathrm{K}$ & $E$ & S. B. & S. Ö. & F. B. & O. Ö. & T. Ö. & $\begin{array}{l}\text { M. } \\
\text { Ö. }\end{array}$ & $f$ & $\%$ \\
\hline 1 & Adalet & 3 & 1 & - & 1 & - & 1 & 1 & 1 & 4 & 1,36 \\
\hline 2 & Ağaç & 7 & 2 & 4 & 2 & - & 3 & - & - & 9 & 3,06 \\
\hline 3 & Aile & 2 & - & - & - & - & - & - & 2 & 2 & 0,68 \\
\hline 4 & Akıl & - & 2 & - & - & - & - & 2 & - & 2 & 0,68 \\
\hline 5 & Akarsu & 1 & - & - & - & - & 1 & - & - & 1 & 0,34 \\
\hline 6 & Anne & 3 & - & - & - & 2 & - & - & 1 & 2 & 0,68 \\
\hline 7 & Araç & 1 & - & - & - & - & - & 1 & - & 1 & 0,34 \\
\hline 8 & Armağan & 1 & - & - & - & - & - & - & 1 & 1 & 0,34 \\
\hline 9 & Aşk & 1 & 1 & - & - & - & - & 2 & - & 2 & 0,68 \\
\hline 10 & Aşure & - & 1 & 1 & - & - & - & - & - & 1 & 0,34 \\
\hline 11 & At & 1 & - & - & - & - & - & 1 & - & 1 & 0,34 \\
\hline 12 & Atardamar & 2 & - & - & 1 & - & 1 & - & - & 2 & 0,68 \\
\hline 13 & Aydınlatıcı & 1 & - & - & - & - & - & 1 & - & 1 & 0,34 \\
\hline 14 & Ayna & 1 & - & - & - & - & - & 1 & - & 1 & 0,34 \\
\hline 15 & Baba & 2 & 2 & 1 & & 1 & & 1 & 1 & 4 & 1,36 \\
\hline 16 & Barış & 1 & - & - & - & 1 & - & - & - & 1 & 0,34 \\
\hline 17 & Beyin & 1 & 1 & - & - & - & - & 1 & 1 & 2 & 0,68 \\
\hline 18 & Beyin Fırtınası & - & 1 & - & - & 1 & - & - & - & 1 & 0,34 \\
\hline 19 & Bilgi & 2 & - & - & - & 1 & 1 & - & - & 2 & 0,68 \\
\hline 20 & Bina & 2 & - & - & 1 & - & 1 & - & - & 2 & 0,68 \\
\hline 21 & $\begin{array}{l}\text { Balık-karınca } \\
\text { dengesi }\end{array}$ & - & 1 & 1 & - & - & - & - & - & 1 & 0,34 \\
\hline 22 & Beyaz Güvercin & 1 & - & - & - & - & - & - & 1 & 1 & 0,34 \\
\hline 23 & Bulut & 1 & - & - & - & - & - & 1 & - & 1 & 0,34 \\
\hline 24 & Çı̆̆ & 1 & - & - & - & - & 1 & - & - & 1 & 0,34 \\
\hline 25 & Çiçek & 1 & 1 & - & - & 1 & 1 & - & - & 2 & 0,68 \\
\hline 26 & Çikolata & 1 & - & - & - & - & - & - & 1 & 1 & 0,34 \\
\hline 27 & Çocuk & 2 & - & - & - & 1 & - & 1 & - & 2 & 0,68 \\
\hline 28 & Çoğunluk & 1 & - & - & - & - & 1 & - & - & 1 & 0,34 \\
\hline 29 & Çok seslilik & 1 & - & 1 & - & - & - & - & - & 1 & 0,34 \\
\hline 30 & Delik kova & - & 1 & - & - & - & - & 1 & - & 1 & 0,34 \\
\hline 31 & Demir & 1 & 2 & - & - & 3 & - & - & - & 3 & 1,02 \\
\hline 32 & Denetim & 1 & - & - & - & - & 1 & - & - & 1 & 0,34 \\
\hline 33 & Deniz & 2 & - & - & - & - & - & 2 & - & 2 & 0,68 \\
\hline 34 & Denizaltı & 1 & - & - & - & 1 & - & - & - & 1 & 0,34 \\
\hline 35 & Devlet & 1 & - & 1 & - & - & - & - & - & 1 & 0,34 \\
\hline 36 & Din & 1 & - & - & - & - & - & 1 & - & 1 & 0,34 \\
\hline 37 & Doğa & 2 & 1 & - & - & - & - & 2 & 1 & 3 & 1,02 \\
\hline 38 & Dost & - & 1 & - & - & 1 & - & - & - & 1 & 0,34 \\
\hline 39 & Dünya & 2 & - & 1 & - & 1 & - & - & - & 2 & 0,68 \\
\hline 40 & Düşünce özgürlüğü & - & 1 & - & 1 & - & - & - & - & 1 & 0,34 \\
\hline 41 & Düşünür & 1 & - & - & 1 & - & - & - & - & 1 & 0,34 \\
\hline 42 & Ekmek & 2 & 1 & 2 & - & 1 & - & - & - & 3 & 1,02 \\
\hline 43 & Emperyalizm makası & - & 1 & 1 & - & - & - & - & - & 1 & 0,34 \\
\hline 44 & Eski yazı & 1 & - & - & - & - & - & 1 & - & 1 & 0,34 \\
\hline 45 & Eşitlik & 8 & 1 & - & 2 & 6 & 1 & - & - & 9 & 3,06 \\
\hline 46 & Ev & 1 & - & - & - & - & - & 1 & - & 1 & 0,34 \\
\hline 47 & Eylem & 1 & - & - & - & - & 1 & - & - & 1 & 0,34 \\
\hline
\end{tabular}




\begin{tabular}{|c|c|c|c|c|c|c|c|c|c|c|c|}
\hline 48 & Fidan & 1 & 1 & 1 & - & - & 1 & - & - & 2 & 0,68 \\
\hline 49 & Gelin & - & 1 & - & - & - & - & 1 & - & 1 & 0,34 \\
\hline 50 & Giyim mağazası & 1 & - & - & - & - & - & - & 1 & 1 & 0,34 \\
\hline 51 & Gölge & 1 & - & 1 & - & - & - & - & - & 1 & 0,34 \\
\hline 52 & Gökkuşağı & 1 & 3 & 1 & 1 & - & - & 1 & 1 & 4 & 1,36 \\
\hline 53 & Gökyüzü & 3 & 1 & - & 1 & - & 1 & 2 & - & 4 & 1,36 \\
\hline 54 & Güç & 1 & - & 1 & - & - & - & - & - & 1 & 0,34 \\
\hline 55 & Güneş & 15 & 2 & 5 & 3 & - & 3 & 4 & 2 & 17 & 5,78 \\
\hline 56 & Güven & 1 & - & - & - & - & 1 & - & - & 1 & 0,34 \\
\hline 57 & Halkın egemenliği & 1 & - & - & - & - & 1 & - & - & 1 & 0,34 \\
\hline 58 & Halkın sesi & 1 & - & - & - & - & - & - & 1 & 1 & 0,34 \\
\hline 59 & Harp & 1 & - & - & - & - & - & 1 & - & 1 & 0,34 \\
\hline 60 & Hava & 2 & - & - & 1 & - & - & - & 1 & 2 & 0,68 \\
\hline 61 & Hayal & 2 & - & 1 & - & 1 & - & - & - & 2 & 0,68 \\
\hline 62 & Hayat & 3 & 3 & 1 & 1 & 1 & - & 3 & - & 6 & 2,04 \\
\hline 63 & Hayatın anlamı & 1 & - & - & 1 & - & - & - & - & 1 & 0,34 \\
\hline 64 & Hoşaf & 1 & - & 1 & - & - & - & - & - & 1 & 0,34 \\
\hline 65 & Işık & - & 2 & - & 1 & - & 1 & - & - & 2 & 0,68 \\
\hline 66 & îkiz kardeş & 1 & - & 1 & - & - & - & - & - & 1 & 0,34 \\
\hline 67 & İnanç & - & 1 & - & - & 1 & - & - & - & 1 & 0,34 \\
\hline 68 & İnsan & 1 & 1 & - & 1 & - & - & 1 & - & 2 & 0,68 \\
\hline 69 & İnsanın eli ayağı & 1 & - & - & - & - & 1 & - & - & 1 & 0,34 \\
\hline 70 & İyilik & 1 & - & - & - & - & 1 & - & - & 1 & 0,34 \\
\hline 71 & İyinin kötüsü & - & 1 & - & - & - & - & 1 & - & 1 & 0,34 \\
\hline 72 & Kadın & 1 & - & 1 & - & - & - & - & - & 1 & 0,34 \\
\hline 73 & Kaktüs & 1 & - & 1 & - & - & - & - & - & 1 & 0,34 \\
\hline 74 & Kalkan & 3 & 1 & - & - & - & - & 1 & 3 & 4 & 1,36 \\
\hline 75 & Kalp & 1 & 1 & - & 1 & - & 1 & - & - & 2 & 0,68 \\
\hline 76 & Kanser & - & 1 & 1 & - & - & - & - & - & 1 & 0,34 \\
\hline 77 & Kar çiçeği & 1 & - & 1 & - & - & - & - & - & 1 & 0,34 \\
\hline 78 & Kardeş & - & 1 & 1 & - & - & - & - & - & 1 & 0,34 \\
\hline 79 & Karşılıksız aşk & 1 & - & 1 & - & - & - & - & - & 1 & 0,34 \\
\hline 80 & Katil & - & 1 & - & - & - & - & 1 & - & 1 & 0,34 \\
\hline 81 & Kavram & 1 & - & - & - & 1 & - & - & - & 1 & 0,34 \\
\hline 82 & Kılıç & 1 & - & - & - & - & - & 1 & - & 1 & 0,34 \\
\hline 83 & Kitap & 3 & - & - & - & - & 2 & 1 & - & 3 & 1,02 \\
\hline 84 & Kök & 1 & - & - & 1 & - & - & - & - & 1 & 0,34 \\
\hline 85 & Kuş & 8 & 1 & 2 & 1 & - & 1 & 3 & 2 & 9 & 3,06 \\
\hline 86 & Kuşun kanadı & 1 & - & - & 1 & - & - & - & - & 1 & 0,34 \\
\hline 87 & Lastik & - & 1 & - & 1 & - & - & - & - & 1 & 0,34 \\
\hline 88 & Mağaza & - & 1 & - & - & 1 & - & - & - & 1 & 0,34 \\
\hline 89 & Mahkeme & 1 & - & - & - & - & 1 & - & - & 1 & 0,34 \\
\hline 90 & Makine & - & 1 & 1 & - & - & - & - & - & 1 & 0,34 \\
\hline 91 & Masal & - & 1 & - & - & - & - & 1 & - & 1 & 0,34 \\
\hline 92 & Martı & 1 & - & - & 1 & - & - & - & - & 1 & 0,34 \\
\hline 93 & Matematik & 2 & - & - & 1 & - & - & 1 & - & 2 & 0,68 \\
\hline 94 & Milletin yüreği & - & 1 & - & 1 & - & - & - & - & 1 & 0,34 \\
\hline 95 & Mutluluk & 1 & - & - & - & - & 1 & - & - & 1 & 0,34 \\
\hline 96 & Namus & 1 & - & 1 & - & - & - & - & - & 1 & 0,34 \\
\hline 97 & Nar & - & 1 & 1 & - & - & - & - & - & 1 & 0,34 \\
\hline 98 & Nefes & 4 & 1 & - & 1 & 1 & 1 & 1 & 1 & 5 & 1,70 \\
\hline 99 & Ok & - & 1 & - & - & - & - & - & 1 & 1 & 0,34 \\
\hline
\end{tabular}




\begin{tabular}{|c|c|c|c|c|c|c|c|c|c|c|c|}
\hline 101 & Okul & 1 & - & - & - & - & - & 1 & - & 1 & 0,34 \\
\hline 102 & Okyanus & 1 & - & 1 & - & - & - & - & - & 1 & 0,34 \\
\hline 103 & Organizma & - & 1 & - & - & - & - & - & 1 & 1 & 0,34 \\
\hline 104 & Orkestra & 2 & - & - & 1 & - & - & - & 1 & 2 & 0,68 \\
\hline 105 & Oyun & 1 & - & - & 1 & - & - & - & - & 1 & 0,34 \\
\hline 106 & Öğrenci & 1 & - & - & - & - & - & 1 & - & 1 & 0,34 \\
\hline 107 & Öğretmen & 2 & 1 & - & 1 & - & 1 & - & 1 & 3 & 1,02 \\
\hline 108 & Özgürlük & 14 & 3 & 3 & 3 & 4 & 2 & 1 & 4 & 17 & 5,78 \\
\hline 109 & Para & 2 & 1 & 1 & 1 & 1 & - & - & - & 3 & 1,02 \\
\hline 110 & Pedal & 1 & - & - & - & - & 1 & - & - & 1 & 0,34 \\
\hline 111 & Plan & - & 1 & - & - & - & - & 1 & - & 1 & 0,34 \\
\hline 112 & Portakal & - & 1 & - & - & - & - & 1 & - & 1 & 0,34 \\
\hline 113 & Renk & 1 & - & - & - & - & 1 & - & - & 1 & 0,34 \\
\hline 114 & Rüya & 1 & - & 1 & - & - & - & - & - & 1 & 0,34 \\
\hline 115 & Sevgi & 3 & - & - & 2 & - & - & - & 1 & 3 & 1,02 \\
\hline 116 & Sevgili & - & 1 & - & - & - & - & 1 & - & 1 & 0,34 \\
\hline 117 & Sifir & - & 1 & - & - & 1 & - & - & - & 1 & 0,34 \\
\hline 118 & Sinif & - & 1 & - & - & 1 & - & - & - & 1 & 0,34 \\
\hline 119 & Simetri & 1 & - & - & 1 & - & - & - & - & 1 & 0,34 \\
\hline 120 & Spor & 1 & - & - & 1 & - & - & - & - & 1 & 0,34 \\
\hline 121 & $\mathrm{Su}$ & 14 & 1 & 5 & 1 & 1 & 2 & 4 & 2 & 15 & 5,10 \\
\hline 122 & Tahterevalli & - & 1 & - & 1 & - & - & - & - & 1 & 0,34 \\
\hline 123 & Tarifsiz & 1 & - & 1 & - & - & - & - & - & 1 & 0,34 \\
\hline 124 & Tavşan & - & 1 & - & - & - & - & 1 & - & 1 & 0,34 \\
\hline 125 & Tatil & 1 & - & - & 1 & - & - & - & - & 1 & 0,34 \\
\hline 126 & Tedavi & 1 & - & - & 1 & - & - & - & - & 1 & 0,34 \\
\hline 127 & Terazi & 10 & - & 2 & 1 & - & 1 & 3 & 3 & 10 & 3,40 \\
\hline 128 & Tohum & 1 & - & 1 & - & - & - & - & - & 1 & 0,34 \\
\hline 129 & Toprak & 1 & 1 & 1 & 1 & - & - & - & - & 1 & 0,34 \\
\hline 130 & Trafik kuralı & 1 & - & - & - & - & - & - & 1 & 1 & 0,34 \\
\hline 131 & Tramvay & - & 1 & - & - & - & - & - & - & 1 & 0,34 \\
\hline 132 & Tren & 3 & 1 & - & 1 & 2 & - & 1 & - & 4 & 1,36 \\
\hline 133 & Türlü yemeği & 1 & - & - & - & - & 1 & - & - & 1 & 0,34 \\
\hline 134 & \begin{tabular}{|l|} 
Twitter \\
\end{tabular} & 1 & - & - & 1 & - & - & - & - & 1 & 0,34 \\
\hline 135 & Uçurtma & 2 & - & - & 1 & - & - & 1 & - & 1 & 0,34 \\
\hline 136 & Uzay aracı & 1 & - & 1 & - & - & - & - & - & 1 & 0,34 \\
\hline 137 & Ülke & 1 & - & - & - & - & 1 & - & - & 1 & 0,34 \\
\hline 138 & Vicdan & 2 & 2 & 2 & 1 & 1 & - & - & - & 4 & 1,36 \\
\hline 139 & Wifi & - & 1 & - & - & 1 & - & - & - & 1 & 0,34 \\
\hline 140 & Yalan & - & 1 & - & - & 1 & - & - & - & 1 & 0,34 \\
\hline 141 & Yemek & 1 & - & - & - & - & 1 & - & - & 1 & 0,34 \\
\hline 142 & Yıldız & - & 1 & 1 & - & - & - & - & - & 1 & 0,34 \\
\hline 143 & Yırtık poşet & - & 1 & - & - & - & - & - & 1 & 1 & 0,34 \\
\hline 144 & Yok & 1 & - & - & 1 & - & - & - & - & 1 & 0,34 \\
\hline 145 & Yokluk & 1 & - & - & - & - & - & 1 & - & 1 & 0,34 \\
\hline 146 & Yonca & 1 & - & - & - & - & - & 1 & - & 1 & 0,34 \\
\hline 147 & Yönetim & 1 & - & - & - & 1 & - & - & - & 1 & 0,34 \\
\hline 148 & Yurt & 1 & - & 1 & - & - & - & - & - & 1 & 0,34 \\
\hline 149 & Zincir & 1 & - & - & - & - & - & - & 1 & 1 & 0,34 \\
\hline \multicolumn{2}{|c|}{ Toplam } & 219 & 75 & 60 & 55 & 34 & 43 & 63 & 39 & 294 & 100 \\
\hline
\end{tabular}


Tablo 1'e göre öğretmen adaylarının demokrasi kavramına yönelik olarak 149 farklı metafor geliştirdiği görülmektedir. Bu durum çeşitli branşlara sahip olan öğretmen adaylarının demokrasi kavramını farklı algılamaları ve bu sonucunun yansıması ile açıklanabilir. Ayrıca öğretmen adaylarının demokrasi kavramını geniş bir çerçevede değerlendirdikleri de düşünülebilir. Öğretmen adayları bu metaforlardan en fazla özgürlük ( $f=17)$, güneş ( $f=17)$, tahterevalli $(f=15)$, su $(f=15)$, terazi $(f=10)$, ağaç $(f=9)$, eşitlik $(f=9)$, kuş $(f=9)$, hayat $(f=6)$, adalet $(f=4)$, baba $(f=4)$, gökkuşağı $(f=4)$, gökyüzü $(f=4)$, kalkan $(f=4)$, nefes $(f=5)$, tren $(f=4)$ ve vicdan $(f=4)$ metaforları üzerinde durmaktadırlar.

Öğretmen adaylarının geliştirdikleri metaforlar Yüce ve Demir (2011)'in “Polis adaylarının demokrasi kavramına ilişkin algılarıın metaforlar aracılığıyla incelenmesi” adlı çalışmasından faydalanılarak kategorilere ayrıımıştır. Her metafor öğretmen adaylarının yaptıkları açıklamalar kapsamında metaforun kaynağından atfedilen düşünce kapsamında gruplandırıımıştır. Bu bağlamda elde edilen bulgulara Tablo 2 'de yer verilmektedir:

Tablo 2. Demokrasi Kategorilerini Oluşturan Verilerin Listesi

\begin{tabular}{|c|c|c|c|c|c|}
\hline \multirow{2}{*}{$\begin{array}{l}\text { Demokrasi } \\
\text { Kategorileri }\end{array}$} & \multirow[t]{2}{*}{ Metafor Adları } & \multicolumn{2}{|c|}{ Metafor } & \multicolumn{2}{|c|}{ Öğrenci } \\
\hline & & $f$ & $\%$ & $f$ & $\%$ \\
\hline $\begin{array}{l}\text { Barış aracı olarak } \\
\text { demokrasi }\end{array}$ & $\begin{array}{l}\text { Barış (1), beyaz güvercin (1) çikolata (1), din (1), fidan } \\
(1) \text {, mutluluk (1), su (1), iyilik (1). }\end{array}$ & 8 & 4,21 & 8 & 2,72 \\
\hline $\begin{array}{l}\text { Değerli ve yol } \\
\text { gösteren bir } \\
\text { varlık olarak } \\
\text { demokrasi }\end{array}$ & $\begin{array}{l}\text { Akarsu (1), akıl (1), anne (2), araç (1), aydınlık (1), bilgi } \\
\text { (2), güneş (13), ışı (3), kitap (3), plan (1), öğretmen (1), } \\
\text { tren (4), tramvay (1), uzay aracı (1), yıldız (1). }\end{array}$ & 15 & 7,89 & 36 & 12,24 \\
\hline $\begin{array}{l}\text { Bakış açısına } \\
\text { göre değişen bir } \\
\text { unsur olarak } \\
\text { demokrasi }\end{array}$ & $\begin{array}{l}\text { Ağaç (3), aşk (2), at (1), ayna (1), berrak su (1), bina (1), } \\
\text { bulut (1), çocuk (1), çiçek (1), delik bir kova (1), doğa } \\
\text { (2), dost (1), dünya (1), düşünür (1), eski yazı (1), eylem } \\
\text { (1), gelin (1), gökyüzü (1), gölge (1), hava (1), hayal (1), } \\
\text { hayat (2), hoşaf (1), insan (1), iyinin kötüsü (1), kadın (1), } \\
\text { kaktüs (1), kanser (1), karşılıksız aşk (1), kavram (1), } \\
\text { kuşun kanadı (1), makine (1), matematik (1), namus (1), } \\
\text { orkestra (1), oyun (1), para (1), rüya (1), su (1), tarifsiz } \\
\text { (1), tavşan (1), toprak (1), trafik kuralı (1), vicdan (4), } \\
\text { yalan (1), yırtık poşet (1), yokluk (1), }\end{array}$ & 48 & 25,26 & 55 & 18,70 \\
\hline $\begin{array}{ll}\text { Eşitlik aracı } \\
\text { olarak } \\
\text { demokrasi }\end{array}$ & $\begin{array}{l}\text { Adalet (4), aile (1), anne (1), baba (3), çocuk (1), devlet } \\
\text { (1), eşitlik (9), gökyüzü (1), güneş (1), kardeş (1), } \\
\text { mahkeme (1), masal (1), matematik (1), ok (1), } \\
\text { öğretmen (1), portakal (1), sevgi (1), sıfır (1), simetri (1), } \\
\text { spor (1), su (1), terazi (10), vicdan (1), yok (1). }\end{array}$ & 24 & 12,63 & 48 & 16,32 \\
\hline $\begin{array}{l}\text { Farklılıkların bir } \\
\text { arada } \\
\text { bulunduğu bir } \\
\text { yapı olarak } \\
\text { demokrasi }\end{array}$ & $\begin{array}{l}\text { Ağaç (2), aşure (1), çok sesin uyumu (1), deniz (1), dünya } \\
\text { (1), giyim mağazası (1), gökkuşağı (4), mağaza (1), okul } \\
\text { (1), okyanus (1), orkestra (1), sınıf (1), renk (1), türlü } \\
\text { yemeği (1). }\end{array}$ & 14 & 7,36 & 18 & 6,12 \\
\hline $\begin{array}{l}\text { Gelişip } \\
\text { olgunlaşan bir } \\
\text { varlık olarak } \\
\text { demokrasi }\end{array}$ & $\begin{array}{l}\text { Ağaç (1), akıl (1), beyin (1), bina (1), demir (1), hayat (1), } \\
\text { kalp (1), lastik (1), kar çiçeği (1), öğrenci (1), pedal (1), } \\
\text { sevgi (1), tohum (2), ülke (1). }\end{array}$ & 14 & 7,36 & 15 & 5,10 \\
\hline $\begin{array}{l}\text { Güç unsuru } \\
\text { olarak } \\
\text { demokrasi }\end{array}$ & $\begin{array}{l}\text { Ağaç (2), aile (1), atardamar (1), baba (1), balık-karınca } \\
\text { dengesi (1), çoğunluk (1), çı̆̆ (2), demir (1), } \\
\text { emperyalizmin makası (1), fidan (1), güç (1), inanç (1), } \\
\text { kalkan (4), katil (1), kılıç (1), kök (1), milletin yüreği (1), }\end{array}$ & 23 & 12,10 & 30 & 10,20 \\
\hline
\end{tabular}




\begin{tabular}{|l|l|l|l|l|l|}
\hline & $\begin{array}{l}\text { nar (2), para (2), tahterevalli (1), tedavi (1), yönetim (1), } \\
\text { yurt (1). }\end{array}$ & & & \\
\hline $\begin{array}{l}\text { Özgürlük simgesi } \\
\text { olarak } \\
\text { demokrasi }\end{array}$ & $\begin{array}{l}\text { Armağan (1), deniz (1), deniz atı (1), düşünce özgürlüğü } \\
\text { (1), gökyüzü (1), hayatın anlamı (1), insan (1), kuş (10), } \\
\text { martı (1), özgürlük (16), tatil (1), twitter (1), uçurtma (2). }\end{array}$ & 13 & 6,84 & 38 & 12,92 \\
\hline $\begin{array}{l}\text { Sistem unsuru } \\
\text { olarak } \\
\text { demokrasi }\end{array}$ & $\begin{array}{l}\text { Beyin (1), demir (1), denetim (1), doğa (1), ekmek (1), } \\
\text { güneş (1), güven (1), halk (1),halkın sesi (1), hayat (1), } \\
\text { insanın eli ayağı (1), kalp (1), nefes (2), organizma (1), } \\
\text { özgürlük (1), su (5), yemek (1), yonca (1), zincir (1). }\end{array}$ & 10 & 25 & 8,50 \\
\hline $\begin{array}{l}\text { Zorunluluk ya da (1), } \\
\text { gereksinim } \\
\text { olarak } \\
\text { demokrasi }\end{array}$ & $\begin{array}{l}\text { Atardamar (1), çiçek (1), ekmek (2), ev (1), güneş (1), } \\
\text { harp (1), hava (1), hayat (2), nefes (3), su (6), sevgi (1), } \\
\text { sevgili (1), wifi (1). }\end{array}$ & 6,31 & 21 & 7,14 \\
\hline & & 190 & 100 & 294 & 100 \\
\hline
\end{tabular}

Tablo 2'ye göre öğretmen adaylarının geliştirdikleri metaforlar çeşitli kategorilere ayrımıştır. Öğretmen adayları en fazla bakış açısına göre değişen bir unsur olarak demokrasi ( $f=48)$, eşitlik aracı olarak demokrasi $(f=24)$, güç unsuru olarak demokrasi $(f=23)$, sistem unsuru olarak demokrasi ( $f=19)$ kategorilerine ait metaforlar geliştirmişlerdir. Öğretmen adaylarının en az metafor geliştirdikleri kategori ise barış aracı olarak demokrasi $(f=8)$ kategorisidir. Buna göre öğretmen adaylarının demokrasi kavramını değişen bir unsur, eşitlik aracı, güç unsuru, sistem unsuru olarak daha çok gördükleri; barış aracı olarak ise daha az gördükleri söylenebilir. Aşağıda kategorileri oluşturan metaforların öğretmen adayları tarafından tanımlamalarına ilişkin örnekler yer almaktadır:

\section{Kategori: Barış Aracı Olarak Demokrasi Kategorisine Ait Yapılan Tanımlamalar}

M.Ö.Ö.A. "Demokrasi beyaz güvercin gibidir. Çünkü bir semboldür, barış ve huzur getireceği söylenir."

T.Ö.ö.A. "Demokrasi din gibidir. Çünkü özgürlük sağlar."

\section{Kategori: Değerli ve Yol Gösteren Bir Varlık Olarak Demokrasi Kategorisine Ait Yapılan Tanımlamalar}

O.ö.Ö.A. "Demokrasi kitap gibidir. Çünkü sayfaları karıştırmadan verim alınmaz."

T.Ö.Ö.A. "Demokrasi güneş gibidir. Çünkü insanlar onunla aydınlığa kavuşur."

O.Ö.Ö.A. "Demokrasi güneş gibidir. Çünkü karanlığı aydınlatır."

\section{Kategori: Bakış Açısına Göre Değişen Bir Unsur Olarak Demokrasi Kategorisine Ait Yapılan Tanımlamalar:}

T.Ö.Ö.A. "Demokrasi tavşan gibidir. Çünkü ışığı görünce donup kalır."

O.Ö.Ö.A. "Demokrasi ağaç gibidir. Çünkü ne kadar köklü olursa o kadar sağlam olur."

M.Ö.Ö.A. "Demokrasi trafik kuralı gibidir. Çünkü hep bahsedilir, hiç uygulanmaz."

S.Ö.ö.A. "Demokrasi orkestra gibidir. Çünkü başındaki şef orkestrayı nasıl yönetiyorsa demokrasi de öyle yönetilir."

F.B.Ö.A. "Demokrasi matematik gibidir. Çünkü her bireyin kararına değer verir."

\section{Kategori: Eşitlik Aracı Olarak Demokrasi Kategorisine Ait Yapılan Tanımlamalar}

F.B.Ö.A. "Demokrasi eşitlik gibidir. Çünkü herkesin eşit hakları vardır."

S.B.Ö.A. "Demokrasi kardeş gibidir. Çünkü her şeyden herkese bir pay verir."

T.Ö.ö.A. "Demokrasi terazi gibidir. Çünkü eşitliği sağlar.” 
M.Ö.Ö.A. "Demokrasi baba gibidir. Çünkü baba evdeki eşitliği, özgürlüğü belirleyendir."

5. Kategori: Farklılıkların Bir Arada Bulunduğu Bir Yapı Olarak Demokrasi Kategorisine Ait Yapılan Tanımlamalar

M.ö.Ö.A. "Demokrasi giyim mağazası gibidir. Çünkü mağazada o kadar karışık kıyafetlerin içinden kendi kıyafetini seçtiğin gibi demokrasiyle de toplumlar istediği iktidarları seçerler."

S.Ö.Ö.A. "Demokrasi dünya gibidir. Çünkü herkesi içinde barındırır."

S.B.Ö.A. "Demokrasi çok sesin uyumu gibidir. Çünkü karşılıklı olarak saygı gerektirir."

T.Ö.Ö.A. "Demokrasi deniz gibidir. Çünkü uçsuz bucaksız anlayış ve saygı getirir."

S.B.Ö.A. "Demokrasi gökkuşağı gibidir. Çünkü bütün renkleri içinde barındırır."

6. Kategori: Gelişip Olgunlaşan Bir Varlık Olarak Demokrasi Kategorisine Ait Yapılan Tanımlamalar:

T.Ö.Ö.A. "Demokrasi beyin gibidir. Çünkü kullandıkça gelişir, aksi halde körelir."

S.Ö.Ö.A. "Demokrasi bina gibidir. Çünkü herkes bir tuğla koyar."

F.B.Ö.A. "Demokrasi hayat gibidir. Çünkü toplumun haline-tavrına, duruşuna ve tercihlerine göre şekillenmektedir."

S.B.Ö.A. "Demokrasi kar çiçeği gibidir. Çünkü zor şartlarda yetişir ama etrafı güzelleştirir."

7. Kategori: Güç Unsuru Olarak Demokrasi Kategorisine Ait Yapılan Tanımlamalar

S.Ö.Ö.A. "Demokrasi para gibidir. Çünkü para kimdeyse demokrasi onun malıdır."

S.B.Ö.A. "Demokrasi güç gibidir. Çünkü gücü olmayanın yetkisi de olmaz."

T.Ö.Ö.A. "Demokrasi kılı̧̧ gibidir. Çünkü kimi keseceği belli olmaz."

S.Ö.Ö.A. "Demokrasi ağaç gibidir. Çünkü herkesi gölgesi altına alır."

8. Kategori: Özgürlük Simgesi Olarak Demokrasi Kategorisine Ait Yapılan Tanımlamalar

M.Ö.ö.A. "Demokrasi özgürlük gibidir. Çünkü düşüncelerimizi özgürce ifade edip savunabiliriz.”

T.Ö.ö.A. "Demokrasi özgürlük gibidir. Çünkü insan demokrasi ile fikirlerini rahatça ifade edebilir."

S.Ö.ö.A. "Demokrasi uçurtma gibidir. Çünkü göklerde olabildiğince özgür ama ucu sapasağlam ve bir millete bağlı."

F.B.Ö.A. "Demokrasi özgürlük gibidir. Çünkü halkın kendi iradesini kullanarak kendi kendini yönetmesidir."

T.Ö.Ö.A. "Demokrasi gökyüzü gibidir. Çünkü kuşlar en özgür canlılardır.”

9. Kategori: Sistem Unsuru Olarak Demokrasi Kategorisine Ait Yapılan Tanımlamalar

O.Ö.Ö.A. "Demokrasi güven gibidir. Çünkü onsuz asla olmaz."

T.Ö.ö.A. "Demokrasi doğa gibidir. Çünkü her şey bir sistem içinde işler."

10. Kategori: Zorunluluk ya da Gereksinim Olarak Demokrasi Kategorisine Ait Yapılan Tanımlamalar

S.Ö.Ö.A. "Demokrasi nefes gibidir. Çünkü insan yaşamı için en gerekli şeydir."

F.B.Ö.A. "Demokrasi ekmek gibidir. Çünkü onsuz yaşanmaz."

T.Ö.Ö.A. "Demokrasi ev gibidir. Çünkü insanlara hak verir, yaşam verir." 
Tablo 3'te öğretmen adaylarının demokrasi kategorilerinin cinsiyetine göre dağılımına ait bulgulara yer verilmektedir:

Tablo 3. Demokrasi Kategorilerinin Cinsiyetlere Göre Dağılımı

\begin{tabular}{|l|l|l|l|}
\hline \multirow{2}{*}{ Demokrasi Kategorisi } & \multicolumn{2}{l|}{ Cinsiyet } & \multirow{2}{*}{ Toplam } \\
\cline { 2 - 4 } & Kız & Erkek & \\
\hline Barış aracı olarak demokrasi & 6 & 3 & 9 \\
\hline Değerli ve yol gösteren bir varlık olarak demokrasi & 30 & 6 & 36 \\
\hline Bakış açısına göre değişen bir unsur olarak demokrasi & 36 & 16 & 52 \\
\hline Eşitlik aracı olarak demokrasi & 39 & 9 & 48 \\
\hline Farklılıkların bir arada bulunduğu bir yapı olarak demokrasi & 13 & 6 & 19 \\
\hline Gelişip olgunlaşan bir varlık olarak demokrasi & 9 & 6 & 15 \\
\hline Güç unsuru olarak demokrasi & 19 & 12 & 31 \\
\hline Özgürlük simgesi olarak demokrasi & 30 & 8 & 38 \\
\hline Sistem unsun olarak demokrasi & 20 & 5 & 25 \\
\hline Zorunluluk ya da gereksinim olarak demokrasi & 17 & 4 & 21 \\
\hline Toplam & 219 & 75 & 294 \\
\hline
\end{tabular}

Tabloya göre kız öğretmen adayları demokrasi kavramını en fazla eşitlik aracı olarak demokrasi ( $f=39)$, bakış açısına göre değişen bir unsur olarak demokrasi $(f=36)$, değerli ve yol gösteren bir varlık olarak demokrasi $(f=30)$ ve özgürlük simgesi olarak demokrasi $(f=30)$ olarak algılamaktadırlar. Erkek öğretmen adayları ise demokrasi kavramını en fazla bakış açısına göre değişen bir unsur olarak demokrasi ( $f=16)$, güç unsuru olarak demokrasi $(f=10)$, eşitlik aracı olarak demokrasi $(f=9)$ ve özgürlük simgesi olarak demokrasi $(f=8)$ olarak algılamaktadırlar. Kız öğretmen adaylarının en fazla metafor oluşturduğu kategorilerden biri olan değerli ve yol gösteren bir varlık olarak demokrasi kategorisi, erkek öğretmen adaylarının en fazla metafor geliştirdiği kategorilerden biri değildir. Buna karşlık güç unsuru olarak demokrasi kategorisi erkek öğretmen adaylarının en fazla metafor geliştirdiği kategorilerden biri olurken kız öğretmen adayları ise bu kategoriye yönelik daha az metafor geliştirmişlerdir.

Tablo 4'te demokrasi kategorilerinin öğretmen adaylarının branşlarına göre dağııımına ait bulgulara yer verilmektedir:

Tablo 4. Demokrasi Kategorilerinin Öğretmen Adaylarının Branşlarına Göre Dağııımı

\begin{tabular}{|l|l|l|l|l|l|l|l|}
\hline \multirow{2}{*}{ Demokrasi Kategorisi } & \multicolumn{6}{|l|}{ Öğretmen Adaylarının Branşları } & Toplam \\
\cline { 2 - 9 } & $\begin{array}{l}\text { S. } \\
\text { B. }\end{array}$ & S. Ö. & F. B. & O. Ö. & T. Ö. & $\begin{array}{l}\text { M. } \\
\text { Ö. }\end{array}$ & \\
\hline Barış aracı olarak demokrasi & 1 & - & 1 & 2 & 2 & 2 & 8 \\
\hline $\begin{array}{l}\text { Değerli ve yol gösteren bir varlık olarak } \\
\text { demokrasi }\end{array}$ & 5 & 3 & 5 & 10 & 10 & 2 & 35 \\
\hline $\begin{array}{l}\text { Bakış açısına göre değişen bir unsur olarak } \\
\text { demokrasi }\end{array}$ & 17 & 12 & 3 & 3 & 17 & 3 & 55 \\
\hline Eşitlik aracı olarak demokrasi & 5 & 11 & 10 & 4 & 9 & 9 & 48 \\
\hline $\begin{array}{l}\text { Farklılıkların bir arada bulunduğu bir yapı } \\
\text { olarak demokrasi }\end{array}$ & 6 & 2 & 2 & 3 & 2 & 3 & 18 \\
\hline Gelişip olgunlaşan bir varlık olarak demokrasi & 4 & 5 & 1 & 2 & 3 & - & 15 \\
\hline Güç unsuru olarak demokrasi & 8 & 7 & 3 & 5 & 3 & 5 & 31 \\
\hline Özgürlük simgesi olarak demokrasi & 5 & 12 & 5 & 3 & 6 & 7 & 38 \\
\hline Sistem unsun olarak demokrasi & 5 & 1 & 1 & 10 & 4 & 4 & 25 \\
\hline Zorunluluk ya da gereksinim olarak demokrasi & 4 & 2 & 3 & 1 & 7 & 4 & 21 \\
\hline Toplam & 60 & 55 & 34 & 43 & 63 & 39 & 294 \\
\hline
\end{tabular}


Tablo incelendiğinde branşlara göre öğretmen adaylarının demokrasi kavramını farklı bakış açılarıyla algıladıkları görülmektedir. Buna göre S.B. öğretmen adayları demokrasi kavramını en fazla bakış açısına göre değişen bir unsur olarak demokrasi $(f=17), S$.Ö. öğretmen adayları bakış açısına göre değişen bir unsur olarak demokrasi ( $f=12$ ) ve özgürlük simgesi olarak demokrasi ( $f=12)$, F.Ö. öğretmen adayları eşitlik aracı olarak demokrasi $(f=10)$, O.Ö. öğretmen adayları değerli ve yol gösteren bir varlık olarak demokrasi $(f=10)$ ve sistem unsun olarak demokrasi $(f=10)$, T.Ö. öğretmen adayları bakış açısına göre değişen bir unsur olarak demokrasi ( $f=17$ ) ve M.Ö. öğretmen adayları eşitlik aracı olarak demokrasi ( $f=9$ ) olarak görmektedirler. Buna göre, S.B., S.Ö. ve T.Ö. öğretmen adaylarının demokrasi kavramına bakış açılarının benzer olduğu; T.Ö. ve M.Ö. öğretmen adaylarının demokrasi kavramına bakış açılarının benzer olduğu görülmektedir. O.Ö. öğretmen adaylarının ise demokrasi kavramını diğer branşlara göre daha farklı algıladıkları söylenebilir.

\section{Tartışma ve Sonuç}

Öğretmen adayları, demokrasi kavramına ilişkin 149 farklı metafor geliştirmiştir. Bu çalışmada öğretmen adayları bu metaforlardan en fazla özgürlük, güneş, tahterevalli, su, terazi, ağaç, eşitlik, kuş, hayat, adalet, baba, gökkuşağı, gökyüzü, kalkan, nefes, tren ve vicdan metaforları üzerinde durmuşlardır. Yüce ve Demir'in (2011) çalışmasında polis adayları demokrasi kavramını oran olarak en fazla sırasıyla kuş, bukalemun, insan, terazi, aslan, kurt, su, arı, karınca, ağaç ve doğa kavramları ile ilişkilendirmişlerdir. Dündar'ın (2012) çalışmasında ilköğretim öğrencileri demokrasiyi en fazla gökkuşağı, güneş, dünya, çiçek, yıldız, su, doğa, yaşam ve cennet kavramlarına benzetmektedirler. Gömleksiz, Kan ve Öner'in (2012) çalışmasında demokrasi kavramı özgür insan, insan, aile, deniz, aşk ve hayat kavramları ile ilişkilendirilmiştir. ibret, Recepoğlu, Oğuz ve Recepoğlu'nun (2015) benzer bir çalışmasında da yükseköğretim öğrencileri demokrasi kavramına yönelik olarak en fazla özgürlük, eşitlik, güneş, su, hayat, kuş ve terazi metaforlarını üretmişlerdir. Nasırcı ve Sadık'ın (2017) çalışmasında sınıf öğretmeni adayları demokrasi kavramını daha çok eşitlik, su, hava, güneş, çiçek, kuş, anne ve ekmek kavramları ile ilişkilendirmişlerdir. Literatürdeki çalışmalardan elde edilen sonuçlara göre demokrasi kavramı en fazla kuş, su, ağaç, gökkuşağı, güneş, hayat/yaşam, özgürlük, terazi ve eşitlik kavramlarına benzetilmektedir. Bu durum bu çalışmadan elde edilen bulguları da destekler niteliktedir. Ural (1999) demokrasi kavramının günümüzde çeşitli anlamlar ifade ettiğini ve demokrasinin en belirgin özelliğinin hak ve özgürlükler üzerine olduğunu belirtmektedir. Heywood (1999) demokrasiyi güçlülerin güçsüzleri yönetmesi olarak açıklamaktadır. Demir (2013) ise demokrasiyi ulaşılması gereken ideal olarak ifade etmektedir. Görüldüğg̈ üzere demokrasi literatürde farklı görüş ve bakış açılarıyla açıklanmışır. Bu çalışmada da öğretmen adaylarının demokrasiyi 149 farkı metaforla ilişkilendirmesi demokrasiye ilişkin farklı görüşlerin olduğunu ortaya koymaktadır. Literatürde demokrasinin farklı bakış açılarıyla tanımlanması bu çalışmadan elde edilen sonucu destekler niteliktedir. Kozikoğlu'nun (2017) çalışmasında da öğretmen adaylarının demokratik eğilimleri ile farklılıklara saygı düzeyleri arasında anlamlı bir ilişki bulunmuştur. Bu çalışma bir metafor çalışması olmasa da elde edilen sonuçta öğretmen adaylarının farklııkları vurgulaması bu araştırmada öğretmen adaylarının demokrasiyi çok sayıda farklı metaforlarla açıklamalarını desteklemektedir.

Çalışmada öğretmen adaylarının geliştirdikleri metaforlar çeşitli kategorilere ayrılıı̧ırı. Öğretmen adayları demokrasiyi değişen bir unsur olarak demokrasi, eşitlik aracı olarak demokrasi, güç unsuru olarak demokrasi, sistem unsuru olarak demokrasi olarak algılamaktadırlar. Sarı ve Sadık'ın (2011) çalışmasında öğretmen adayları tarafından geliştirilen metaforlar, çoğunlukla eşitlik, kişisel çıkarlar, bağımsızlık, çaba ve hayal temaları ile ilgilidir. Yüce ve Demir'in (2011) çalışmasında demokrasiye yönelik geliştirilen metaforlar on üç farklı kategori altında toplanmıştır. Bu araştırmada polis adaylarının demokrasi kavramını daha çok özgürlük anlayışı, güç anlayışı, duruma göre değişen bir varlık, gelişen bir varlık, eşitlik anlayışı ve farklı unsurları içeren bir varlık olarak algıladıkları görülmektedir. Dündar'ın (2012) ilköğretim öğrencilerinin 
demokratik algılarını incelediği çalışmasında demokrasi kavramına ilişkin eşitlik simgesi olarak, kurallarla var olan, birlikte yaşamayı öğreten ve rüya gibi bir demokrasi kategorileri elde edilmiştir. Sadık ve Sarı'nın (2012) bir diğer çalışmasında da ilköğretim öğrencilerinin demokrasi ile ilgili geliştirdikleri metaforların daha çok temel hak ve özgürlükler, toplumsal yaşam, çoğulculuk, iş bölümü, emek, hayal, gelişme ve yaşam kaynağı temalarına ilişkin olduğu görülmektedir. Gömleksiz, Kan ve Öner'in (2012) Sosyal Bilgiler öğretmen adaylarının demokrasi kavramına ilişkin metaforlarını incelediği çalışmada, geliştirilen metaforlara yönelik eşitlik ve özgürlük, çeşitliliği barındırma, kargaşa ve zayıflık, gereklilik ve ulaşılamama kategorileri elde edilmiştir. Yağan Güder ve Yıldırım'ın (2014) okul öncesi öğretmen adaylarının metafor algılarını ele aldığı çalışmada öğretmen adaylarının geliştirdikleri metaforlardan özgürlük, farklı düşüncelerin bir arada bulunması, işbirliği, yaşamsal önem taşıması, eşitlik, adalet, inisiyatife bağlı değişebilme ve imkansızlık yönü ile demokrasi kategorileri oluşturulmuştur. Öğretmen adayları bu kategorilerden en fazla eşitlik-adalet kategorisine yönelik metafor geliştirmişlerdir. Nasırcı ve Sadık'ın (2017) çalışmasında sınıf öğretmeni adaylarının metaforlarından zorunluluk, eşitlik, toplumsal düzen, çaba, özgürlük, kişisel çıkarlar, güç, ilerleme, korunabilirlik ve hiçlik kategorileri geliştirilmiştir. Öğretmen adayları en fazla zorunluluk, eşitlik, toplumsal düzen, çaba, özgürlük ve kişisel kazançlara ilişkin metafor geliştirmişlerdir. Literatürde demokrasiyi çeşitli algılama biçimlerine yönelik olarak çeşitli kategorilerin oluştuğu görülmektedir. Literatüdeki kategorilerin bu çalışma ile kısmen benzerlik gösterdiği söylenebilir.

Çalışmada kız öğretmen adaylarının demokrasi kavramını eşitlik aracı olarak demokrasi, bakış açııına göre değişen bir unsur olarak demokrasi, değerli ve yol gösteren bir varlık olarak demokrasi ve özgürlük simgesi olarak demokrasi olarak algıladıkları görülmektedir. Erkek öğretmen adayları ise demokrasi kavramını en fazla bakış açısına göre değişen bir unsur olarak demokrasi, güç unsuru olarak demokrasi, eşitlik aracı olarak demokrasi ve özgürlük simgesi olarak demokrasi olarak algılamaktadırlar. Kız öğretmen adaylarının en fazla metafor oluşturduğu kategorilerden biri olan değerli ve yol gösteren bir varlık olarak demokrasi kategorisi, erkek öğretmen adaylarının en fazla metafor geliştirdiği kategorilerden biri değildir. Buna karşılık güç unsuru olarak demokrasi kategorisi erkek öğretmen adaylarının en fazla metafor geliştirdiği kategorilerden biri olurken kız öğretmen adayları ise bu kategoriye yönelik daha az metafor geliştirmişlerdir. Saracaloğlu'nun (2001) çalışmasında Beden Eğitimi öğretmeni adaylarının demokratik tutumları cinsiyete göre farklııı göstermektedir. Sadık ve Sarı́nın (2012) çalışmasında demokrasi kavramını temel hak ve özgürlükler, toplumsal yaşamın ve toplumsal gelişmenin temeli ve yaşam kaynağı olarak algılayan kız öğrencilerin oranının erkek öğrencilerden daha fazla olduğu; çoğulculuk, işbölümü ve emek olarak algılama durumunun kız ve erkek öğrencilerin oranları arasında büyük farklılıklar olmadığı tespit edilmiştir. Karatekin, Merey ve Kuş (2013) çalışmasında öğretmenlerin demokratik tutumlarında kızların lehine anlamlı bir farklılık oluşmuştur. Nasırcı ve Sadık'ın (2017) çalışmasında kız sınıf öğretmeni adaylarının demokrasi ile ilgili daha çok zorunluluk, eşitlik, çaba, güç, toplumsal düzen, özgürlük kategorilerine ait metaforlar geliştirdikleri görülmektedir. Erkek öğretmen adayları ise bu kavrama yönelik zorunluluk, toplumsal düzen, eşitlik, kişisel çıkarlar ve özgürlük bazında metaforlar geliştirmişlerdir. Ancak bazı çalışmalarda da öğretmenlerin ve öğretmen adaylarının demokratik tutum ve algılarının cinsiyete göre farklılaşmadığı görülmektedir (Elkatmış \& Toptaş, 2015; Genç \& Kalafat, 2007; ibret, vd. 2015; Karadağ, Baloğlu \& Yalçınkayalar, 2006; Karatekin, Merey \& Kuş, 2013; Kontaş, Selçuk \& Polat, 2016). Bu bağlamda demokrasiyi algılama biçiminin cinsiyete göre değişebileceği söylenebilir. Literatürdeki çalışmalar ve bu çalışmadan elde edilen sonuçlar cinsiyete göre demokrasi algısının değişebileceği göstermektedir.

Çalışmada branşlara göre öğretmen adaylarının demokrasi kavramını farklı bakış açılarıyla algıladıkları ortaya çıkmıştır. Buna göre Sosyal Bilgiler öğretmen adayları demokrasi kavramını en fazla bakış açısına göre değişen bir unsur olarak demokrasi, Sınıf Öğretmenliği öğretmen adayları bakış açııına göre değişen bir unsur olarak demokrasi ve özgürlük simgesi olarak demokrasi, Fen Öğretmenliği öğretmen adayları eşitlik aracı olarak demokrasi, Okul Öncesi öğretmen adayları değerli ve yol gösteren bir varlık olarak demokrasi 
ve sistem unsun olarak demokrasi, Türkçe Öğretmenliği öğretmen adayları bakış açısına göre değişen bir unsur olarak demokrasi ve Matematik Öğretmenliği öğretmen adayları eşitlik aracı olarak demokrasi olarak görmektedirler. Sosyal Bilgiler, Sınıf Öğretmenliği ve Türkçe Öğretmenliği öğretmen adaylarının demokrasi kavramına bakış açılarının benzer olduğu; Türkçe Öğretmenliği ve Matematik Öğretmenliği öğretmen adaylarının demokrasi kavramına bakış açılarının benzer olduğu görülmektedir. Okul Öncesi öğretmen adaylarının ise demokrasi kavramını diğer branşlara göre daha farklı algıladıkları söylenebilir. Genç ve Kalafat'ın (2007) çalışmasında öğretmen adaylarının demokratik tutumlarının anabilim dallarına göre farklılaştı̆̆ görülmektedir. İbret vd. 'nin (2015) çalışmasında Sosyal Bilgiler, Fen Bilgisi, Türkçe ve Sınıf öğretmeni adayları demokrasiyi en fazla özgürlük simgesi olarak demokrasi olarak algılarken Okulöncesi öğretmen adayları ve Matematik öğretmen adayları ise demokrasiyi en çok, değerli ve yol gösteren bir varlık olarak demokrasi olarak algıladıkları görülmektedir. Literatürdeki bu çalışmaların sonuçları ile bu araştırmanın sonuçlarının kısmen benzerlik gösterdiği söylenebilir. ỉki çalışmada da, Okul öncesi öğretmen adaylarının demokrasiyi algılama biçimi yönünden benzerlik gösterdiği görülmektedir.

\section{Kaynakça / References}

Anderson, R. D. (2001). Metaphors of dictatorship and democracy: Change in the Russian political lexican and the transformation of Russian politics. Slavic Review, 60(2), 312-335.

Akın, U. \& Özdemir, M. (2009). Öğretmen adaylarının demokratik değerlerinin çeşitli değişkenler açısından incelenmesi: Eğitim Bilimleri Fakültesi örneği. Ankara Üniversitesi Eğitim Bilimleri Fakültesi Dergisi, 42(2), 183-198.

Akşin, S. (2003). Atatürk döneminde demokrasi. Eğitim Araştırmaları, 3(11), 16-22.

Aktaş, M. (2012). Küreselleşme sürecinde ulus devlet ve demokrasi. EKEV Akademi Dergisi. 53(16). 223-234.

Arslan, M. M. \& Bayrakçı, M. (2006). Metaforik düşünme ve öğrenme yaklaşımının eğitim-öğretim açısından incelenmesi. Milli Eğitim, 171, 100-108.

Aydoğdu, E. (2008). Ilköğretim okullarındaki öğrenci ve öğretmenlerin sahip oldukları okul algıları ile ideal okul algılarının metaforlar (mecazlar) yardımıyla analizi. Yayınlanmamış Yüksek Lisans Tezi, Osmangazi Üniversitesi Fen Bilimleri Enstitüsü, Eskişehir.

Balcı, A. (1999). Metaphorical images of school: School perceptions of students, teachers and parents from four selected schools in Ankara. Yayımlanmamış Doktora tezi, ODTÜ, Ankara.

Koşar, D. (2016). Öğretmen adaylarının üniversite ve öğretim elemanı kavramlarına ilişkin metaforik algıları. International Online Journal of Educational Sciences, 8(3), 113-127.

Cerit, Y. (2008). Öğretmen kavramı ile ilgili metaforlara ilişkin öğrenci, öğretmen ve yöneticilerin görüşleri. Türk Eğitim Bilimleri Dergisi, 6(4), 693-712.

Çankaya, D. \& Seçkin, O. (2004). Demokratik değerlerin benimsenmesi açısından öğretmen ve öğretmen adaylarının görüş ve tutumları. Uluslararası Demokrasi Eğitimi Sempozyumu Bildiriler Kitabı, (ss.461-466). 
Çelikten, M. (2006). Kültür ve öğretmen metaforları. Erciyes Üniversitesi Sosyal Bilimler Enstitüsü Dergisi, 21(2): 269-283.

Dahl, R. A. (2001). Demokrasi üstüne (Çev. B. Kadıoğlu). Ankara: Phoenix Yayınevi.

Demir, N. (2010). Demokrasi'nin temel ilkeleri ve modern demokrasi kuramları. Ege Akademik Bakış, 10(2), 597-611.

Demir, H. (2013). Demokrasi Düşüncesinin Gelişimi Bağlamında Demokrasi Ve Demokrasi Karşıtı Görüşler: Giıovanni Sartori Ve Carl Schmitt. Yayımlanmamış Yüksek Lisans Tezi, Hacettepe Üniversitesi Sosyal Bilimler Enstitüsü, Ankara.

Demoulin, D. F. \& Kolstad, R. (2000). Assessing the gains of behavioral dynamics essential for success in a democracy for teacher education students. College Student Journal, 34(3), 417-422.

Dewey (t.y.). On democracy. Erişim: http://www.radicalacademy.com/adiphilpolitics15es. html http://www.radicalacademy.com/adiphilpolitics15es.html adresinden 15.08.2018 tarihinde alınmıştır.

Dündar, H. (2012). Elemantary students' metaphors for democracy. Educational Research and Reviews, 7(24), 509-516.

Elkatmış, M. \& Toptaş, V. (2015). Sınıf öğretmeni adaylarının demokratik tutumlarının incelenmesi. YYü Eğitim Fakültesi Dergisi, 12(1), 128-144. Ersoy, F. (2016). Fenomenoloji. Ahmet Saban, Ali Ersoy (Ed.), Eğitimde Nitel Araştırma Desenleri (51-109). Ankara: Anı Yayıncılık.

Genç, S. Z. (2006). Demokratik kazanımların gerçekleştirilmesinde ilköğretim öğretmenlerinin etkililiğinin değerlendirilmesi. Milli Eğitim Dergisi, 35(171), 43-54.

Genç, S. Z. \& Kalafat, T. (2007). Öğretmen adaylarının demokratik tutumları ile problem çözme becerilerinin çeşitli değişkenler açısından incelenmesi. Pamukkale Üniversitesi Eğitim Fakültesi Dergisi, 2(22), 10-22.

Gömleksiz, M. N.; Kan, A. Ü. \& Öner, Ü. (2012). Sosyal Bilgiler öğretmen adaylarının bir değer olarak demokrasi kavramına ilişkin metafor algıları. Değerler Eğitimi Dergisi, 10(24), 79-100.

Güder, S. Y. \& Yıldırım, A. (2014). Okul öncesi öğretmen adaylarının demokrasiye ilişkin metaforları. Adıyaman Üniversitesi Sosyal Bilimler Enstitüsü Dergisi,7(16), 151-170.

Gürşimşek, I. \& Göregenli, M. (2004). Öğretmen adayları ve öğretmenlerde demokratik tutumlar, değerler ve demokrasiye ilişkin inançlar. Uluslararası Demokrasi Eğitimi Sempozyumu Bildiriler Kitabı, (ss.77-85).

Heywood, A. (1999). Demokrasi, Sosyal ve Siyasal Teori (108-121), Siyasal Kitabevi.

ibret, B. Ü.; Receoğlu, E.; Oğuz, S. \& Recepoğlu, S. (2015). Yükseköğretim öğrencilerinin "demokrasi" kavramına yönelik metafor algılarının incelenmesi. International Conference on Quality in Higher Education, December 02-04 2015, Sakarya Üniversitesi, Ed. Muzaffer ELMAS, Aytekin IŞMAN, Colleen SEXTON, Douglas FRANKLIN, Teresa FRANKLIN, Ahmet ESKICUMALI, 670-680.

Karadağ, E.; Baloğlu, N. \& Yalçınkayalar, P. (2006). illköğretim okulu yöneticilerinin öğretmenler tarafından algılanan demokratik tutumları ile öğretmenlerin demokratik değerleri üzerine ilişkisel bir araştırma. Değerler Eğitimi Dergisi, 4 (12), 65-82.

Karatekin, K.; Merey, Z. \& Kuş, Z. (2013). Öğretmen adayları ve öğretmenlerin demokratik tutumlarının çeşitli değişkenler açısından incelenmesi. Kastamonu Eğitim Dergisi,21(2), 561-574. 
Kılıç, D. (2010). Changes in democratic attitudes of trainee teachers over time. Social Behavior and Personality, 38(9), 1211-1218.

Kıncal, R. Y. \& Işık, H. (2003). Demokratik eğitim ve demokratik değerler. Eğitim Araştırmaları, 3(11), 54-58.

Kontaş, H.; Selçuk, E. \& Polat, M. (2016). Ortaokul öğretmenlerinin demokratik tutumları ile öğrencilerin demokratik değerlere sahip olma düzeylerinin incelenmesi. The Journal of Academic Social Science Studies, 44,141-151.

Kozikoğlu, i. (2017). Analyzing the relationship between prospective teachers' democratic tendencies and their respect for differences levels. International Journal of Advanced Education and Research, 2(6), 19-29.

Kuçuradi, ì. (1998). Yirmibirinci yüzyılın eşiğinde demokrasi kavramı ve sorunları. Edebiyat Fakültesi Dergisi, Cumhuriyetimizin 75. Yılı Özel Sayısı, 21-27.

Kuşat, N. (2011). Demokratikleşme sürecini tamamlayamamış toplumların ekonomik ve siyasi açıdan değerlendirilmesi: Sürdürülebilir demokrasi. Yönetim ve Ekonomi, 1(18). 125-137.

Lakoff, G. \& Johnson, M. (2005). Metaforlar, hayat, anlam ve dil (Çev. G. Y. Demir). İstanbul: Paradigma Yayınları.

Levin, B. (2008). The educational requirement for democracy. https://onlinelibrary.wiley.com 15.08.2018 tarihinde erişilmiştir.

Levine, P.M. (2005). Metaphors and images of classrooms. Kappa Delta Pi Record, 41(4), 172-175.

Marshall G. (2009). Sosyoloji Sözlüğü. (Çev. O. Akınhay ve D. Kömürcü). Ankara: Bilim ve Sanat Yayınları.

Morgan, G. (1998). Yönetim ve örgüt teorilerinde metafor. (Çev. G. Bulut). İstanbul: MESS Yayın.

Nasırcl, H. \& Sadık, F. (2017). Investigating primary school teachers' perception about democracy though metaphor analysis. European Journal of Educational Research, 7(1), 121-132.

Ocak, G. \& Gündüz, M. (2006). Eğitim fakültesini yeni kazanan öğretmen adaylarının öğretmenlik mesleğine giriş dersini almadan önce ve aldıktan sonra öğretmenlik mesleği hakkındaki metaforlarının karşılaştıııması. Afyon Kocatepe Üniversitesi Sosyal Bilimler Dergisi, 8(2), 293-311.

Oğuz, A. (2005). Öğretmen eğitimi programlarında metafor kullanma. XIV. Ulusal Eğitim Bilimleri Kongresi, Pamukkale Üniversitesi Eğitim Fakültesi, 28-30 Eylül 2005, Denizli, Kongre Kitabı, Cilt I, 582- 588, Ankara: Anı Yayıncılık.

Osler, A. \& Starkey, H. (2006). Education for democratic citizenship: A review of research, policy and practice. Research Papers in Education, 21(4), 433-466.

Öztürk, Ç. (2007). Sosyal bilgiler, sınıf ve fen bilgisi öğretmen adaylarının "coğrafya" kavramına yönelik metafor durumları. Ahi Evran Üniversitesi Kırşehir Eğitim Fakültesi Dergisi, 8(2), 55-69.

Palmquist, R. A. (2001). Metaphors are good mirrors: Reflecting on change for teachwer educators. Journal of academic Librainship, 27(1), 185-189.

Parsons, S. C.; Brown, P. U. \& Worley, V. (2004). A metaphor analysis of preservice teachers' reflective writings about diversity. Curriculum and Teaching Dialogue, 6(1), 49-58.

Patton, M. Q. (2014). Nitel araştırma ve değerlendirme yöntemleri. Mesut Bütün, Selçuk Beşir Demir (Çev. Ed.), 3. Baskıdan Çeviri, Ankara: Pegem Akademi Yayıncılık. 
Pektaş, M. \& Kıldan, O. (2009). Farklı branşlardaki öğretmen adaylarının "öğretmen" kavramı ile ilgili geliştirdikleri metaforların karşılaştııılması (A comparison of "teacher" metaphores generated by preservice teachers from different majors). Erzincan Eğitim Fakültesi Dergisi, 11(2), 271-287.

Saban, A. (2004). Giriş düzeyindeki sınıf öğretmeni adaylarının öğretmen kavramına ilişkin ileri sürdükleri metaforlar. Türk Eğitim Bilimleri Dergisi, 2(2), 131-155.

Sarı, M. \& Sadık, F. (2011). Öğretmen adaylarının demokrasi algıları (Çukurova Üniversitesi Örneği). Uluslararası Eğitim Programları ve Öğretim Çalışmaları Dergisi, 1(2), 67-82.

Sadık, F. \& Sarı, M. (2012). Çocuk ve demokrasi: Illköğretim öğrencilerinin demokrasi algılarının metaforlar aracılığıyla incelenmesi. Uluslararası Cumhuriyet Eğitim Dergisi, 1(1), 48-62.

Saracaloğlu, A. S. (2001). Beden eğitimi öğretmeni adaylarının demokratik tutumları. Ege Eğitim Dergisi, 1, 23-30.

Saracaloğlu, A. S.; Evin, i. \& Varol, S. R. (2004). İzmir ilinde çeşitli kurumlarda görev yapan öğretmenler ile öğretmen adaylarının demokratik tutumları üzerine karşılaştırmalı bir araştırma. Kuram ve Uygulamada Eğitim Bilimleri, 4(2), 356-364.

Savaş, A. (2003). Matematik eğitimi ile demokrasi arasındaki ilişki üzerine bir çalışma. Eğitim Araştırmaları, $3(11), 59-63$.

Schmitt, R. (2005). Systematic metaphor analysis as a method of qualitative research. The Qualitative Report, 10(2), 358-394.

Sezgin, F.; Koşar, D.; Koşar, S. \& Er, E. (2017). Öğretmenlerin öğrenciye yönelik metaforlarının belirlenmesine ilişkin nitel bir araştırma. Hacettepe Üniversitesi Eğitim Fakültesi Dergisi, 32(3): 600-611.

Şahin B. (2008). Liberal Demokrasinin Temelleri. In B. Şahin (Ed.) Demokrasi Teorisinde Güncel Tartışmalar, (pp.1-34), Ankara: Orion Yayınları.

Türk Dil Kurumu (2018). Metafor. 15.06.2018 tarihinde http://tdkterim.gov.tr/bts/ 12.07.2018 tarihinde alınmıştır.

Ural, Ş. (1999). Demokrasi kavramı, toplumsal değerler ve birey. Ilahiyat Fakültesi Dergisi, 40(1), 451-459.

Wilkins, C. (1999). Making good citizens: The social and political attitudes of PGCE students. Oxford Review of Education, 25(1-2), 217-230.

Wilkins, C. (2001). Student teachers and attitudes towards race: The role of citizenship education in addressing racism through the curriculum. Westminster Studies in Education, 24(1), 7-21.

Wilkins, C. (2003). Teachers and young citizens: Teachers talk about their role as social educators. Westminster Studies in Education, 26(1), 63-75.

Yağan Güder, S. \& Yıldırım, A. (2014). Okulöncesi öğretmeni adaylarının demokrasiye ilişkin metaforları. Adıyaman Üniversitesi Sosyal Bilimler Enstitüsü Dergisi, 7(16), 151-170.

Yamaç, K. (2010). Bilgi toplumu ve demokrasi üzerine. Türk Kütüphaneciliği, 24(3). 519-525.

Yazıcı, K. (2011). Sosyal bilgiler öğretmen adaylarının demokratik değerlerinin çeşitli değişkenler açısından incelenmesi. Eğitim ve Bilim, 36(159), 165-178. 
Yüce, S. G. \& Demir, Ö. (2011). Polis adaylarının "demokrasi" kavramına ilişkin algılarının metaforlar yoluyla incelenmesi. Polis Bilimleri Dergisi, 13(2), 147-178.

Yıldırım, A. \& Şimşek, H. (2016). Sosyal bilimlerde nitel araştırma yöntemleri. 6. Baskı, Ankara: Seçkin Yayınları.

Yıldııım, A.; Akbaşlı, S. \& Şahin, M. (2010). Sınıf öğretmenleri ve öğretmen adaylarının demokratik inanç düzeylerinin belirlenmesi. E-Journal of New World Sciences Academy, 5(1), 40-48. 